\title{
First simultaneous measurements of peroxyacetyl nitrate (PAN) and ozone at Nam Co in the central Tibetan Plateau: impacts from the PBL evolution and transport processes
}

\author{
Xiaobin $\mathrm{Xu}^{1}$, Hualong Zhang ${ }^{1, \mathrm{a}}$, Weili Lin ${ }^{1,2, \mathrm{~b}}$, Ying Wang ${ }^{1}$, Wanyun $\mathrm{Xu}^{1}$, and Shihui Jia ${ }^{1, \mathrm{c}}$ \\ ${ }^{1}$ State Key Laboratory of Severe Weather \& Key Laboratory for Atmospheric Chemistry of China Meteorological \\ Administration, Chinese Academy of Meteorological Sciences, Beijing, China \\ ${ }^{2}$ Meteorological Observation Center, China Meteorological Administration, Beijing, China \\ ${ }^{a}$ now at: Guangdong Meteorological Observatory, Guangzhou, Guangdong, China \\ ${ }^{b}$ now at: College of Life and Environmental Sciences, Minzu University of China, Beijing, China \\ ${ }^{c}$ now at: School of Environment and Energy, South China University of Technology, Guangzhou, Guangdong, China
}

Correspondence: Xiaobin Xu (xiaobin_xu@189.cn)

Received: 28 August 2017 - Discussion started: 25 September 2017

Revised: 6 February 2018 - Accepted: 30 March 2018 - Published: 17 April 2018

\begin{abstract}
Both peroxyacetyl nitrate (PAN) and ozone $\left(\mathrm{O}_{3}\right)$ are key photochemical products in the atmosphere. Most of the previous in situ observations of both gases have been made in polluted regions and at low-altitude sites. Here we present the first simultaneous measurements of PAN and $\mathrm{O}_{3}$ at $\mathrm{Nam}$ Co (NMC; $30^{\circ} 46^{\prime} \mathrm{N}, 90^{\circ} 57^{\prime} \mathrm{E}, 4745 \mathrm{~m}$ a.s.1.), a remote site in the central Tibetan Plateau (TP). The observations were made during summer periods in 2011 and 2012. The PAN levels averaged $0.36 \mathrm{ppb}$ (range: $0.11-0.76 \mathrm{ppb}$ ) and $0.44 \mathrm{ppb}$ (range: $0.21-0.99 \mathrm{ppb}$ ) during 17-24 August 2011 and 15 May to 13 July 2012, respectively. The $\mathrm{O}_{3}$ level varied from 27.9 to $96.4 \mathrm{ppb}$, with an average of $60.0 \mathrm{ppb}$. Profound diurnal cycles of PAN and $\mathrm{O}_{3}$ were observed with minimum values around 05:00 LT, steep rises in the early morning, and broader platforms of high values during 09:0020:00 LT. The evolution of the planetary boundary layer (PBL) played a key role in shaping the diurnal patterns of both gases, particularly the rapid increases of $\mathrm{PAN}$ and $\mathrm{O}_{3}$ in the early morning. Air entrainment from the free troposphere into the PBL seemed to cause the early-morning increase and be a key factor for sustaining the daytime high concentrations of both gases. The days with higher daytime PBL (about $3 \mathrm{~km}$ ) showed stronger diurnal variations in both gases and were mainly distributed in the drier pre-monsoon period, while those with shallower daytime PBL (about $2 \mathrm{~km}$ ) showed minor diurnal variations and were mainly distributed in the humid monsoon period. Episodes of higher PAN lev-
\end{abstract}

els were occasionally observed at NMC. These PAN episodes were caused either by rapid downward transport of air masses from the middle/upper troposphere or by long-range transport of PAN plumes from north India, north Pakistan, and Nepal. The maximum PAN level in the downward transport cases ranged from 0.5 to $0.7 \mathrm{ppb}$. In the long-range transport case, the PAN level varied in the range of $0.3-1.0 \mathrm{ppb}$, with an average of $0.6 \mathrm{ppb}$. This long-range transport process influenced most of the western and central TP region for about a week in early June 2012. Our results suggest that polluted air masses from South Asia can significantly enhance the PAN level over the TP. As PAN acts as a reservoir of $\mathrm{NO}_{x}$, the impacts of pollution transport from South Asia on tropospheric photochemistry over the TP region deserve further studies.

\section{Introduction}

Peroxyacetyl nitrate (PAN) and ozone $\left(\mathrm{O}_{3}\right)$ are important species in the troposphere. They are toxic for humans and vegetation. Tropospheric $\mathrm{O}_{3}$ contributes significantly to global warming with a radiative forcing of $0.40 \pm 0.20 \mathrm{~W} \mathrm{~m}^{-2}$ (Myhre et al., 2013). Tropospheric $\mathrm{O}_{3}$ originates mainly from photochemical reactions within the troposphere and to a lesser extent from the stratosphere (Lelieveld and Dentener, 2000), while PAN in the tropo- 
sphere is nearly exclusively formed by the oxidation of volatile organic compounds (VOCs) in the presence of nitrogen oxides $\left(\mathrm{NO}_{x}\right)$ (Fischer et al., 2014). PAN is produced in the association reaction between peroxyacetyl radical $\left(\mathrm{CH}_{3} \mathrm{C}(\mathrm{O}) \mathrm{O}_{2}, \mathrm{PA}\right)$ and nitrogen dioxide $\left(\mathrm{NO}_{2}\right)$. As one of the key radicals, PA is produced by oxidation of a number of VOCs (Roberts, 2007; LaFranchi et al., 2009; Fischer et al., 2014). Since both VOCs and $\mathrm{NO}_{x}$ are largely emitted by anthropogenic sources, PAN is primarily produced in and downwind of industrial and populated areas. In additional to anthropogenic sources, PAN is also formed in biomass burning plumes (Tereszchuk et al., 2013; Fischer et al., 2014; Zhu et al., 2015). With different lifetimes at different temperatures (Cox and Roffey, 1977), PAN is unstable under warm conditions, but stays longer in colder environment. Due to this characteristic PAN is ubiquitous in the middle to upper troposphere (Singh, 1987; Talbot et al., 1999; Russo et al., 2003; Kramer et al., 2015) and can be transported at higher altitudes on a global scale. PAN can decompose and release $\mathrm{NO}_{2}$ when it reaches a warm environment, becoming one of the key sources of $\mathrm{NO}_{x}$ in remote areas. This makes PAN an important reservoir of $\mathrm{NO}_{2}$. Inter-comparisons among models and between model and observation show very large PAN differences in many regions of the atmosphere (Thakur et al., 1999; Sudo et al., 2002; von Kuhlmann et al., 2003; Singh et al., 2007), but confirm the important role of PAN in sustaining $\mathrm{O}_{3}$ production over remote regions (Hudman et al., 2004; Zhang et al., 2008). Since tropospheric $\mathrm{O}_{3}$ and $\mathrm{OH}$ are principally controlled by the abundance of $\mathrm{NO}_{x}$, decomposition of PAN may have great implications for the budget of these key atmospheric oxidants. It has been indicated that a regional increase in $\mathrm{O}_{3}$ can be attributed to an intercontinental and even global transport of PAN (Hudman et al., 2004; Fischer et al., 2011) and most of the conveying paths are in the free troposphere, driving PAN plumes traveling to remote areas (Roiger et al., 2011; Pandey Deolal et al., 2013). Thus, a considerable amount of PAN has been detected in remote areas with sparse anthropogenic emissions (Zanis, 2007).

Up to now the main methods to directly obtain the PAN concentration are ground-based and aircraft observations. Although PAN has been measured in a great deal of campaigns for decades, the observational data of PAN have been very inhomogeneously distributed over the world, with most of them being from North America, western Europe, and the Pacific region (Fischer et al., 2014). PAN measurements are extremely lacking in many areas over the Eurasian continent, northeastern Africa, Oceania regions , the Indian Ocean, and the Tibetan Plateau (TP) region.

The TP region covers an area of about $2500000 \mathrm{~km}^{2}$, with an average elevation of about $4000 \mathrm{~m}$ above sea level. The world's highest plateau acts as a heat source in summer, heating the air above and prompting its ascending motion (Yeh et al., 1957). In addition to the thermal effect, the South Asian monsoon also exerts a convergence effect driving the ascending motion (Chen et al., 2012). Accom- panied by the ascending motion, water vapor and air pollutants emitted or formed in the boundary layer can be rapidly transported to the upper troposphere and lower stratosphere (UTLS; Dessler and Sherwood, 2004; Gettelman and Kinnison, 2004; Fu et al., 2006; Lelieveld et al., 2007; Law et al., 2010). Convective transport over the TP and surrounding areas can be clearly tracked by satellite observations of some longer-lived species, such as CO (Park et al., 2007, 2009), PAN (Ungermann et al., 2016), $\mathrm{CH}_{4}$ (Xiong et al., 2009), and HCN (Randel et al., 2010). Elevated concentrations of some relatively short-lived anthropogenic pollutants in the UTLS region are also reported (Park et al., 2008; Tian et al., 2008; Gu et al., 2016). Such rapid, upward transport of pollutants and water vapor may have great implications for atmospheric composition and climate on regional and global scales. Efforts have been made to understand the impacts of upward transport of air masses on the stratosphere over the $\mathrm{TP}$, among which is the potential relationship with the ozone valley over the TP reported by Zhou et al. (1995).

The TP region is very sparsely populated with nearly no industrial emissions of pollutants. Although the TP has been nearly unpolluted, the high altitude and the correspondingly intensified UV radiation make it an interesting region for studies of photochemical products, such as $\mathrm{O}_{3}$ and PAN. However, there have been only sparse reports of measurements of $\mathrm{O}_{3}$ and related species from the TP mainly due to the poor accessibility and logistic difficulties of this vast region. So far, most of the published measurements of $\mathrm{O}_{3}$ and its precursors over the TP have been from sites at the edges of the TP (Ma et al., 2002a, b; Ding and Wang, 2006; Wang et al., 2006; Zhu et al., 2006; Cristofanelli et al., 2010; Xue et al., 2011; Zheng et al., 2011; Ma et al., 2014; Q. Y. Wang et al., 2015; Xu et al., 2016, 2018). Only three publications present measurements of $\mathrm{O}_{3}$ and related species from sites in the central TP, with one reporting data from urban observations (Ran et al., 2014) and two showing results from remote sites (Lin et al., 2015; Yin et al., 2017).

Observational data of PAN from the TP are extremely lacking. The only field observation of ambient PAN in the TP was made by Xue et al. (2011), who measured PAN and other reactive species at Mt. Waliguan, a global atmosphere watch (GAW) station located at the northeast edge of the TP. The average level of PAN was $0.44( \pm 0.14)$ ppb for a 2-week period in summer 2006. This observation offers a preliminary detection of ambient PAN over the northeast TP. So far, there has been no published in situ measurement of PAN from the central TP. In addition to the traditional observation methods, remote sensing techniques can also be applied to acquire the global PAN distribution from satellites (Remedios et al., 2007; Moore and Remedios, 2010; Wiegele et al., 2012; Tereszchuk et al., 2013; Fadnavis et al., 2014). However, the PAN data retrieved from satellite observations need further validations and do not cover the lower and middle troposphere. 
Here we present the first simultaneous measurements of PAN and $\mathrm{O}_{3}$ at a site in the central TP. We study the diurnal variations in observed concentrations and the links to the evolution of the planetary boundary layer (PBL). We also investigate the vertical and horizontal transport and discuss the implications of our measurements.

\section{Observations}

\subsection{Site}

The observations of PAN and other species were made from 11 July to 31 August 2011 and from 15 May to 13 July 2012 at the Nam Co (NMC) Comprehensive Observation and Research Station, Chinese Academy of Sciences (CAS)(NMC: $30^{\circ} 46^{\prime} \mathrm{N}, 90^{\circ} 57^{\prime} \mathrm{E}, 4730 \mathrm{~m}$ a.s.1.). West and north of the NMC site is the Nam Co lake, with the nearest distance to the lake being about $1.5 \mathrm{~km}$. The Nyainqêntanglha Mountains (about 5000-6800 ma.s.1.) stand south and east of the site, with the nearest mountain ridge being more than $20 \mathrm{~km}$ distant from the site. The TP region has a population density of less than 2 person $\mathrm{km}^{-2}$ (http://sedac.ciesin.columbia.edu/ gpw/, last access: 1 April 2018). The largest city of Lhasa, Tibet, is about $120 \mathrm{~km}$ south of the NMC site, far beyond the continuous ridges of the Nyainqêntanglha Mountains. The nearest population center, Dangxiong Township, is located about $35 \mathrm{~km}$ southeast of the NMC site. The direct transport of air pollutants from Lhasa and Dangxiong is limited due to the blocking of the high mountain ridges. There is a road about $1.3 \mathrm{~km}$ southeast of the NMC site, connecting the tourism site of the Nam Co lake to Dangxiong and the No. 109 National Road. More details about NMC and its surrounding can be found in the literature (Ma et al., 2011; Lin et al., 2015; Yin et al., 2017).

\subsection{Instruments and data correction}

Ambient PAN was observed using a PAN analyzer (Meteorologie Consult GmbH, Germany), which consists of an automated gas chromatograph (GC) equipped with an electron capture detector (ECD) and a calibration unit. The equipment is the same one as used in previous observations in Beijing (Zhang et al., 2014) and elsewhere (e.g., Zellweger et al., 2000; J. M. Zhang et al., 2009), with identical setup details depicted in Zhang et al. (2014). The GC with a pre-column and a main column was optimized by the factory for the separation of $\mathrm{PAN}$ and $\mathrm{CCl}_{4}$ at $15^{\circ}$ within $10 \mathrm{~min}$. Purified nitrogen (> 99.999\%, Chengweixin Gases, Beijing, China) was used as carrier gas. A cartridge with $\mathrm{CuSO}_{4} \cdot 5 \mathrm{H}_{2} \mathrm{O}$ was used to humidify the carrier gas before entering the GC columns. This can reduce the effects of varying humidity on the measurements (Flocke et al., 2005). Back-flushing was applied to the pre-column to prevent contamination and shorten analysis time. An NO reference gas (4.5 ppm, Huayuan Gases, Beijing, China) in nitrogen was introduced into the calibra- tion unit, where it reacts with excess acetone vapor under the UV irradiation to yield concentrated PAN. Prior to each campaign the NO reference gas was verified using an NO standard (Air Liquide America Specialty Gases LLC, USA) traceable to the National Institute of Standards and Technology (NIST) reference material. Under similar conditions, the PAN yield was found to be $92 \% \pm 3 \%$ (Volz-Thomas et al., 2002). A continuous, stable flow of known PAN concentration was produced by subsequent dynamic dilution with purified ambient air and supplied to the PAN-GC for calibration. The lower detection limit was 50 ppt. Zellweger et al. (2000) achieved an overall uncertainty of $\pm 3 \%$ under their conditions.

Surface $\mathrm{O}_{3}$ was simultaneously observed using an $\mathrm{O}_{3}$ analyzer (TE 49C, Thermo Environmental Instruments, Inc., USA). The $\mathrm{O}_{3}$ analyzer has a lower detection limit of $1.0 \mathrm{ppb}$ and precision of $\pm 1.0 \mathrm{ppb}$. Before and after each campaign the analyzer was calibrated using an $\mathrm{O}_{3}$ calibrator (TE 49C PS) traceable to the Standard Reference Photometer (SRP) maintained by WMO World Calibration Centre at EMPA, Switzerland (Zellweger et al., 2009). All instruments were housed in a simply constructed one-story building, located $0.15 \mathrm{~km}$ southeast of the station's main building. Ambient air was introduced through Teflon tubing (outer diameter $1 / 4$ in. and $2-3 \mathrm{~m}$ ) to the PAN and $\mathrm{O}_{3}$ analyzer at the flow rate of 2 and $6 \mathrm{~L} \mathrm{~min}^{-1}$, respectively. Meteorological data were collected using automatic meteorological station systems installed at different levels on a tower near the observation building.

Although measurements of PAN have been made previously at some high-altitude sites in other areas using methods similar to ours (Ford et al., 2002; Fischer et al., 2010; Xue et al., 2011; Pandey Deolal et al., 2013), this is the first report of using the GC-ECD instrument for PAN measurement under the conditions of a high-altitude site over $4700 \mathrm{~m}$ a.s.1. To track the performance of the PAN analyzer, frequent calibrations were made during the campaigns (e.g., on 9 and 10 July; 7, 9, 12, 14, 17, and 23 August for 2011 and on 15, 16, and 28 May; 6, 13, 20, 22, and 27 June; 4, 12, and 13 July for 2012) except the period from 16 July to 5 August 2011, where no carrier gas was available for the PAN observation due to a leakage. During the observation period in 2011, the instrument performance was somewhat unstable, probably affected by the extreme ambient conditions at the site. The variation in environment temperature is suspected to have made it hard to keep the ECD inner temperature constant. This sometimes resulted in abrupt fluctuations in the $10 \mathrm{~min}$ chromatographic PAN signals during the measurement period in 2011. The unstable performance of the ECD caused a varying detection sensitivity. Normally, we convert PAN signals of air samples to concentration data based on ratios of signals to theoretical PAN concentration of the standard gas produced during the calibrations. However, the jumping sensitivity made it improper to obtain PAN concentrations using the normal method. Thus, we applied an indirect calibration 
method. Our GC-ECD instrument was optimized for the separation and detection of both PAN and $\mathrm{CCl}_{4}$. Therefore, it was possible to indirectly calculate the PAN concentrations, i.e., by using the ratios of the $\mathrm{PAN}$ to $\mathrm{CCl}_{4}$ signal. Details about the indirect calibration are given in the Supplement.

Although the indirect calibration is a viable way to obtain PAN concentrations, the uncertainty in final data could be larger than the direct calibration primarily due to the two assumptions mentioned in the Supplement and some technical problems with the observation system. We are more confident of the data from 17 to 24 August 2011. During this period, the instruments performed well and the two calibrations in this period gave similar sensitivities. In view of this, we report and analyze in this paper mainly data from 17 to 24 August 2011, together with those obtained from 15 May to 13 July 2012, where our instruments performed well.

\subsection{Meteorological data and analysis}

Local meteorological variables, including temperature, relative humidity, 3-dimensional winds, etc., were observed by corresponding sensors installed at 2,10 , and $20 \mathrm{~m}$ of the meteorological tower at the NMC station. The National Centers for Environmental Prediction (NCEP) reanalysis data, together with the local meteorological data, are used in this paper to facilitate the interpretation of our PAN and $\mathrm{O}_{3}$ measurements. Global Data Assimilation System (GDAS, 3 hourly, $1^{\circ} \times 1^{\circ}$ in longitude and latitude, and 26 pressure levels, http://ready.arl.noaa.gov/gdas1.php, last access: 1 April 2018) data were obtained from National Oceanic and Atmospheric Administration (NOAA) Air Resources Laboratory (ARL). The GDAS data are used as input to the Hybrid Single-Particle Lagrangian Integrated Trajectory (HYSPLIT) model (V4.9) for simulating backward air trajectories ending at 500 and $1500 \mathrm{~m}$ above the NMC site. The HYSPLIT model is developed by NOAA/ARL (Draxler and Hess, 1997). In addition, NCEP FNL (final) Operational Global Analysis data (6 hourly, $1^{\circ} \times 1^{\circ}$ in longitude and latitude, and 26 pressure levels, http://rda.ucar.edu/datasets/ ds083.2/\#!description, last access: 1 April 2018) were acquired from the National Center for Atmospheric Research (NCAR). These data are used to obtain meteorological fields for analyzing weather patterns and air circulations over the TP.

\section{Results and discussion}

\subsection{Surface concentrations of $\mathrm{PAN}$ and $\mathrm{O}_{3}$}

The PAN level averaged $0.36 \mathrm{ppb}$ in the period of $16-25 \mathrm{Au}-$ gust 2011, ranging from 0.11 to $0.76 \mathrm{ppb}$. A clear increasing trend is found in the time series of PAN data in this period. The origin of increasing PAN in this period will be discussed in Sect. 3.4. In 2012, the effective observation covered nearly 2 months (from 15 May to 13 July), long enough to ob- tain the PAN levels under different atmospheric conditions during the South Asian monsoon period. The observed PAN in this period varied from 0.16 to $0.99 \mathrm{ppb}$, with an average of $0.44 \mathrm{ppb}$. This result is close to the PAN levels observed in summer 2006 at Waliguan (WLG), a remote site at the northeastern edge of the TP (Xue et al., 2011). The $\mathrm{O}_{3}$ concentration varied from 27.9 to $96.4 \mathrm{ppb}$, with an average of $60.0 \mathrm{ppb}$, nearly identical to the average $\mathrm{O}_{3}$ level at WLG. There were little day-to-day and diurnal variations when the PAN and $\mathrm{O}_{3}$ measurements from WLG were not impacted by relatively polluted air masses from the eastern sector (Xue et al., 2011). In contrast, our PAN and $\mathrm{O}_{3}$ measurements from NMC show profound variations. The reasons of the variations, particularly the diurnal variations, should be investigated.

It is noteworthy that the NMC site is about $20 \mathrm{~km}$ distant from the Nyainqêntanglha Mountains. Permanent snow cover exits on the mountains. Experiments by Ford et al. (2002) indicated that snowpack at Summit Station, Greenland emitted PAN. Snowpack may also emit $\mathrm{NO}_{x}, \mathrm{HONO}$, etc., and indirectly influence the $\mathrm{O}_{3}$ formation over Summit (Huang et al., 2017). However, the snowpack influence may only play a minor role in the budget of PAN and $\mathrm{O}_{3}$. For example, ambient PAN over the Summit site was dominated by transport instead of snowpack emission though the site is permanently covered with snow (Ford et al., 2002). The annual mean snow line altitude of the Nyainqêntanglha Mountains was about $5.8 \mathrm{~km}$ a.s.l. in 2013 (Zhang et al., 2016). In summer, the snow line is even higher though snow may exist on the glaciers extending to lower elevations ( $\mathrm{Qu}$ et al., 2014). At this time, we cannot exclude the possibility of snowpack influence on our measurements. However, this influence might be very limited because of the large distance between NMC and the snow areas. Therefore, we focus on other factors that may influence the variations in PAN and $\mathrm{O}_{3}$ at NMC.

\subsection{Diurnal cycles of $\mathrm{PAN}$ and $\mathrm{O}_{3}$ and potential impacts from the PBL evolution}

The 10 min PAN and $\mathrm{O}_{3}$ concentrations observed in 2012 were used to obtain the averaged diurnal patterns (Fig. 2). As can be seen in Fig. 2, during nighttime both PAN and $\mathrm{O}_{3}$ show a decreasing trend and reach a valley around 05:00 local time (LT, here LT $=$ Beijing Time $-2 \mathrm{~h}$ ), demonstrating their steady loss during night. From 05:00 to 10:00 LT, both gases can be characterized by a rapid increase, with the average levels of $\mathrm{PAN}$ and $\mathrm{O}_{3}$ being lifted over 0.10 and $15.0 \mathrm{ppb}$, respectively. Subsequently, $\mathrm{O}_{3}$ increases at a much lower rate before reaching its peak around 16:00 LT and then starts to decline. Unlike $\mathrm{O}_{3}$, PAN behaves more fluctuating after its peak time (around 12:00 LT), with a larger deviation from the trace of $\mathrm{O}_{3}$.

It is noteworthy to see the sharp early-morning increase in PAN and $\mathrm{O}_{3}$ as shown in Fig. 2. If the observed in- 


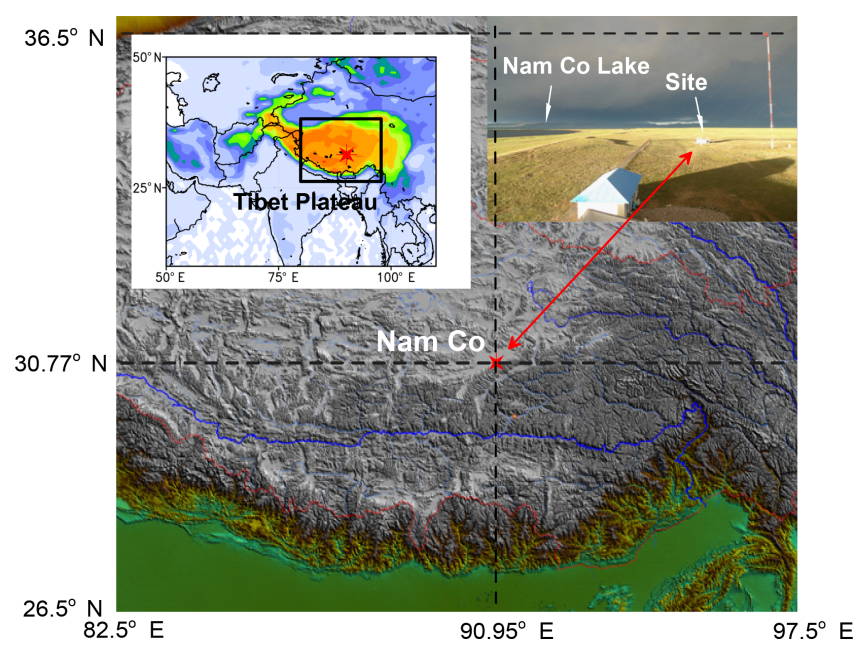

Figure 1. Map showing the location of the observation site and the local environment.

crease in both gases had been caused by photochemical productions, considerable amounts of their precursors would be required to fuel the photochemical reactions. However, according to the EDGAR 3.2 FT2000 database, anthropogenic emissions in the TP are extremely low, with emissions of $\mathrm{NO}_{x}$ and $\mathrm{CO}$ being respectively no more than $0.1 \times 10^{-12}$ and $1 \times 10^{-12} \mathrm{~kg} \mathrm{~m}^{-2} \mathrm{~s}^{-1}$ in the surrounding areas (http://themasites.pbl.nl/tridion/en/themasites/edgar/ emission_data/edgar_32ft2000/index-2.html, last access: 1 April 2018). Surface $\mathrm{NO}_{x}$ at NMC was below the lower detection limit of the commercial $\mathrm{NO}_{x}$ analyzers like TE 42 CTL and Eco Physics CLD 88 p that we deployed there. In addition, the key condition for the photochemistry, i.e., the UV radiation, was not strong enough to drive photochemical reactions in the very early morning (say around 05:00 LT), as the sunrise in that TP area occurs around 06:00 LT in summer. Therefore, it is hypothesized that the main factor driving the rapid PAN and $\mathrm{O}_{3}$ increase in the early morning was not photochemistry but the mixing process during the PBL evolution. To prove this hypothesis, we display scatter plots in Fig. 3, showing the correlations between the increment of $\mathrm{O}_{3}$ concentration $\left(\Delta \mathrm{O}_{3}\right)$ and that of PAN concentration ( $\triangle \mathrm{PAN}$ ) for two time periods of the day, and the correlation between the increments of $\mathrm{O}_{3}$ and temperature $(\Delta \mathrm{T})$. Figure $3 \mathrm{a}$ represents data from the 05:00-09:00 LT period, when the solar radiation becomes gradually intensive. Figure $3 b$ and $c$ show data from the 02:00-04:00 LT period, when no solar radiation is available for the local photochemical reactions.

A significant linear correlation between $\Delta \mathrm{O}_{3}$ and $\triangle \mathrm{PAN}$ is found for both the early-morning period (Fig. 3a) and the dark period (Fig. 3b), with correlation coefficients of 0.745 and 0.711 , respectively. Although photochemical reactions, in which both $\mathrm{O}_{3}$ and PAN are produced, can lead to a $\Delta \mathrm{O}_{3}-$ $\triangle$ PAN correlation, they cannot occur during the dark pe-

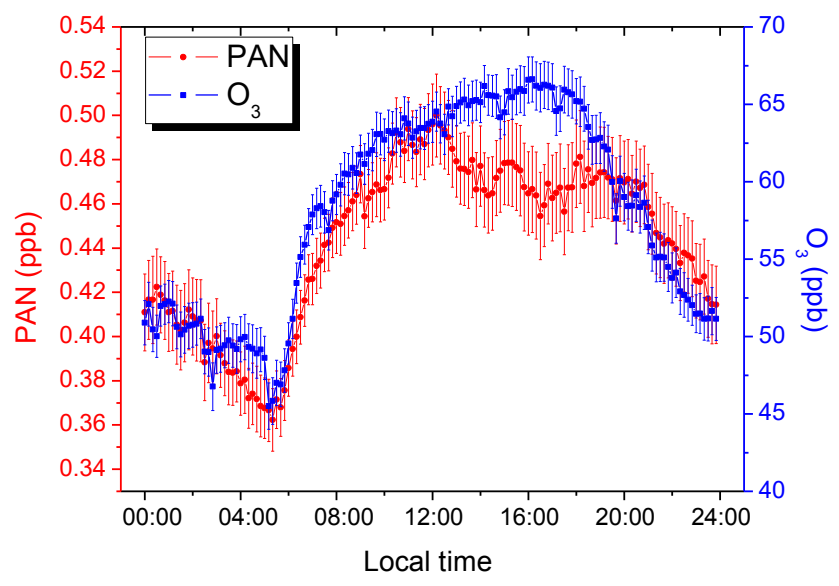

Figure 2. Diurnal patterns of PAN and $\mathrm{O}_{3}$. All data are processed as $10 \mathrm{~min}$ resolution. The vertical bars represent one standard error of the mean.

riod. Therefore, the significant correlation in Fig. 3b should be attributed to some meteorological processes instead of photochemical process. Moreover, the $\Delta \mathrm{O}_{3}-\Delta T$ correlation shown in Fig. 3c further indicates that the concentrations of surface $\mathrm{O}_{3}$ and PAN at the site may be influenced purely by some meteorological processes that change air temperature as well. The net change of $\mathrm{O}_{3}$ could be positive before dawn, and occurred on those days with simultaneously rising PAN and temperature. The rising temperature could be related to the dry adiabatic heating process during air masses descending. Such a process happens when the PBL is extended, not necessarily driven by solar radiation. Downward transport of PAN and $\mathrm{O}_{3}$ may accompany such a process. Therefore, the PBL evolution might have significantly impacted the diurnal variations in $\mathrm{PAN}$ and $\mathrm{O}_{3}$ at $\mathrm{NMC}$.

\subsection{Insight into the PBL evolution}

The evolution of PBL plays one of the key roles in the diurnal variations in surface meteorological parameters and air pollutants, and is influenced by the dominating synoptic situation. It has different diurnal patterns under different synoptic situations. Here we take the $\mathrm{O}_{3}$ enhancement $\left(\Delta \mathrm{O}_{3}\right)$ in the early morning as an indicator quantity to find out major differences in the evolution of the PBL and some related parameters under different synoptic situations. We select 30 days from the observation period in 2012 and separate them into two groups, with Group 1 including 15 days with the greatest $\Delta \mathrm{O}_{3}$ values (High $\Delta \mathrm{O}_{3}$ ) and Group 2 including 15 days with the smallest $\Delta \mathrm{O}_{3}$ values (Low $\Delta \mathrm{O}_{3}$ ). For the two groups, average diurnal variations were calculated for PAN, $\mathrm{O}_{3}$, and some meteorological parameters, i.e., wind speed at $2 \mathrm{~m}$ above ground $\left(W_{\mathrm{s}}\right)$, zonal wind speed at $2 \mathrm{~m}$ above ground $(U)$, meridional wind speed at $2 \mathrm{~m}(V)$, the ratio between the 2 and $10 \mathrm{~m}$ wind speeds (WSR), the temperature difference between 20 and $10 \mathrm{~m}$ (TD), and water vapor 

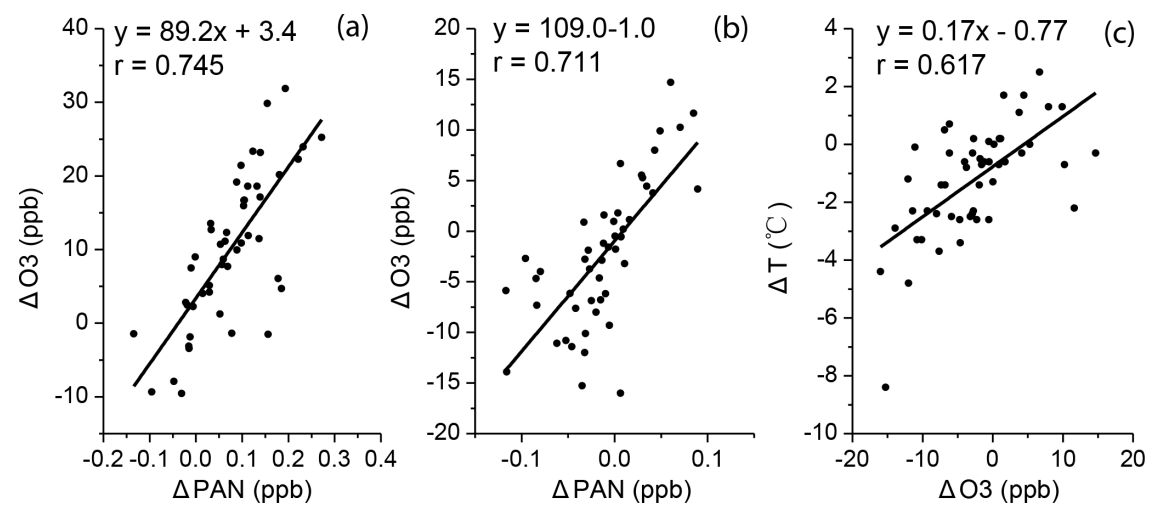

Figure 3. Scatter plots of $\triangle \mathrm{PAN}$ (variation of the PAN concentration), $\Delta \mathrm{O}_{3}$ (variation of the $\mathrm{O}_{3}$ concentration) and $\Delta T$ (variation of temperature) in specific time spans: (a) from 05:00 to 09:00 LT; (b, c) from 02:00 to 04:00 LT. All correlations shown in the figures are statistically significant at $\alpha=0.01$.

pressure (WVP). The obtained diurnal variations are plotted in Fig. 4.

A stable nocturnal boundary layer (NBL) forms gradually in the night (Stull, 1988). A temperature inversion can occur in the NBL, with the air temperature increasing with height. A nocturnal jet may form over the NBL so that a larger gradient of wind speed may exist in the NBL. Such stratification prevents the air from being vertically mixed in the night and is broken in the early morning. As a result, the concentrations of $\mathrm{O}_{3}$ and PAN at the ground-level decrease largely in the nighttime because of chemical and physical losses and increase rapidly in the early morning because of the downward mixing of upper-level air containing more $\mathrm{O}_{3}$ and PAN. This evolution of the PBL, however, can be strongly impacted by some systematic processes so that the day-night differences in the PBL are weakened or even disappear. We believe that the two groups of data presented in Fig. 4 represent approximately two circumstances of the PBL evolution, with the High- $\Delta \mathrm{O}_{3}$ group (Group 1) being less or not impacted and the Low- $\Delta \mathrm{O}_{3}$ group (Group 2) being strongly impacted by the systematic processes.

As can be seen in Fig. 4, the Low- $\Delta \mathrm{O}_{3}$ group showed much smaller diurnal variations in $\mathrm{PAN}, \mathrm{O}_{3}, W_{\mathrm{s}}$, WVP, and WSR, suggesting a weak day-night cycle of the PBL. Compared with the values in the Low- $\Delta \mathrm{O}_{3}$ group, the nighttime values of PAN, $\mathrm{O}_{3}, W_{\mathrm{s}}$, and WSR in the High- $\Delta \mathrm{O}_{3}$ group were much lower, and that of TD much higher. Lower WSR and higher TD in the night indicate a more stable NBL, which explains the lower PAN and $\mathrm{O}_{3}$ levels as discussed above. After dawn the values of PAN, $\mathrm{O}_{3}, W_{\mathrm{s}}$, WSR, and TD in the High- $\Delta \mathrm{O}_{3}$ group changed rapidly back to their daytime levels, indicating the break of the stable NBL. It is noteworthy that there were virtually no or only minor differences in the daytime values of PAN, $W_{\mathrm{s}}$, WSR, and TD between the two groups. The daytime $\mathrm{O}_{3}$ in the High- $\Delta \mathrm{O}_{3}$ group reached significantly higher levels than that in the Low- $\Delta \mathrm{O}_{3}$ group. Moreover, the WVP value in the High- $\Delta \mathrm{O}_{3}$ group was lower than that in the Low- $\Delta \mathrm{O}_{3}$ group during the entire day. These phenomena imply that the High- $\Delta \mathrm{O}_{3}$ group is related to drier days and PBL conditions favoring the increase in surface $\mathrm{O}_{3}$ during daytime (e.g., through downward mixing) and destruction during nighttime, while the Low- $\Delta \mathrm{O}_{3}$ group is related to more humid days and PBL conditions that inhibit the variation in surface $\mathrm{O}_{3}$.

The PBL evolution was investigated in previous field experiments in the TP. Li et al. (2011) found that there were some differences in the diurnal evolution of the PBL structure between dry and rainy seasons. In the dry season, namely the pre-monsoon period, a shallow but strong inversion layer could be clearly observed at night. The occurrence of the inversion layer is high in the pre-monsoon period, simply because the PBL structure is primarily driven by sensible heat (Ma et al., 2005). The outflow of sensible heat at night is massive according to thermal analysis. In the rainy season, a shallower but more persistent wet convection evolves, forcing an efficient exchange of quantities and also comparably smaller gradients of meteorological elements. The daytime PBL height can reach $4-5 \mathrm{~km}$ above the ground in the dry pre-monsoon period, while it is usually about $1-2 \mathrm{~km}$ above the ground in the wet monsoon period (Li et al., 2011; Chen et al., 2013). In our case, prevailing monsoonal features are perceivable in meteorological measurements associated with the Low- $\Delta \mathrm{O}_{3}$ group, such as weaker westerly wind ( $U$ wind, Fig. 4g), stronger southerly wind ( $V$ wind, Fig. 4 h) and higher WVP (Fig. 4d). Unlike the dry season, the convection intensity in the wet season had a much smaller diurnal variation, as suggested by the smaller day-night differences in WSR and TD. Thus, in the wet season, downward transport of PAN and $\mathrm{O}_{3}$ during nighttime might have been much more effective than that in the dry season. This can explain the observed nighttime differences in the PAN and $\mathrm{O}_{3}$ concentrations between the Low- $\Delta \mathrm{O}_{3}$ and High- $\Delta \mathrm{O}_{3}$ groups (Fig. $4 \mathrm{a}$ and $b$ ). 

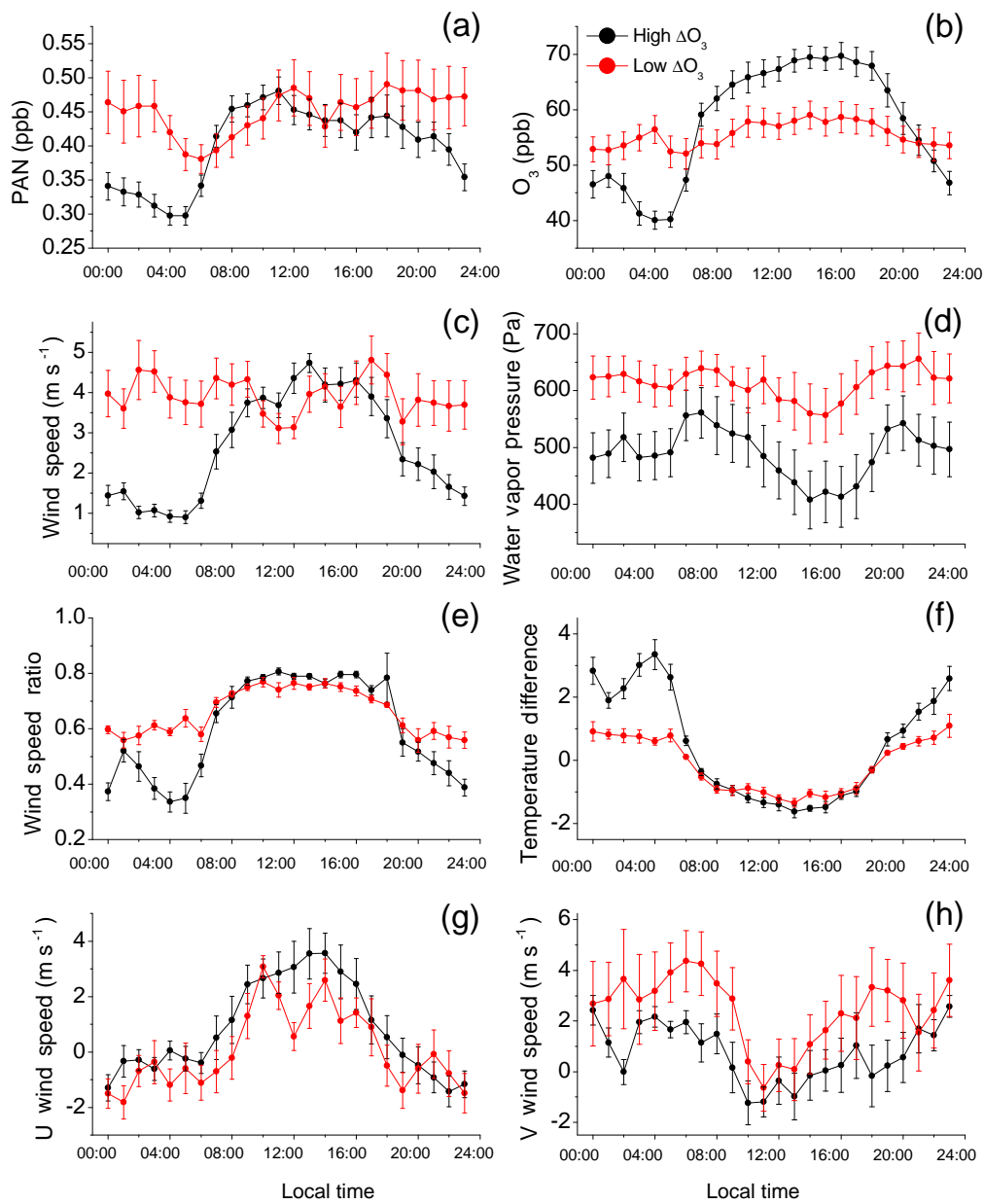

Figure 4. Diurnal patterns of PAN (a), $\mathrm{O}_{3}$ (b), wind speed (c), water vapor pressure (d), wind speed ratio (e, ratio of $10 \mathrm{~m}$ height wind speed and $2 \mathrm{~m}$ height wind speed), temperature difference (f, subtraction of $20 \mathrm{~m}$ height temperature and $10 \mathrm{~m}$ height temperature), $U$ (zonal) wind speed (g) and $V$ (meridional) wind speed . Black curves represent diurnal curves of 15 days with greatest $\Delta \mathrm{O}_{3}$ from 07:00 to 11:00 LT (Group 1), and red curves represent diurnal curves of 15 days with smallest $\Delta \mathrm{O}_{3}$ (Group 2). The vertical bars represent one standard error of the mean.

To gain more details about the two groups of days discussed above, the distribution of the Group 1 and Group 2 days, together with parameters including the PBL height, precipitable water of entire atmosphere (PWAT), WVP, and the PAN and $\mathrm{O}_{3}$ concentrations are shown in Fig. 5. The PBL height and PWAT values are obtained from the NCEP FNL reanalysis data. It can be seen that the surface measured WVP is in good accordance with the PWAT in trend. The whole observation period in 2012 can be divided into the dry period and wet period. The transition between the wet and dry periods can be easily identified based on the changes in the PBL height, and the PWAT and WVP values. It can also be seen by the variation in the daily rainfall at NMC (Fig. S1 in the Supplement). We can see a sudden seasonal change in the middle of June, when the depth of the PBL was suppressed after 16 June 2012 (marked with green bar in Fig. 5) and the water amount became more abundant, suggesting the onset of the South Asian monsoon. The distributions of the two groups of days are labeled on Fig. 5a. Although there are some irregular cases, the High- $\Delta \mathrm{O}_{3}$ days (Group 1) are mostly distributed in the dry period and the Low- $\Delta \mathrm{O}_{3}$ days (Group 2) in the wet period. This supports our analysis in the previous paragraph. The time series of the PBL height indicates that the daily maximum PBL heights in the dry period were much higher than those in the wet period, with only a few exceptions. Such phenomenon agrees with the observational results from Naqu, about $230 \mathrm{~km}$ northeast of NMC (Li et al., 2011). The nocturnal PBL height in the dry period could be extremely low (frequently lower than $200 \mathrm{~m}$ ). This explains the lower nighttime $\mathrm{PAN}$ and $\mathrm{O}_{3}$ values in the High- $\Delta \mathrm{O}_{3}$ group (Fig. 4).

In the pre-monsoon, there may be episodes with monsoon features. An example of this is the period of a few days around early June 2012, where the PBL height was consid- 


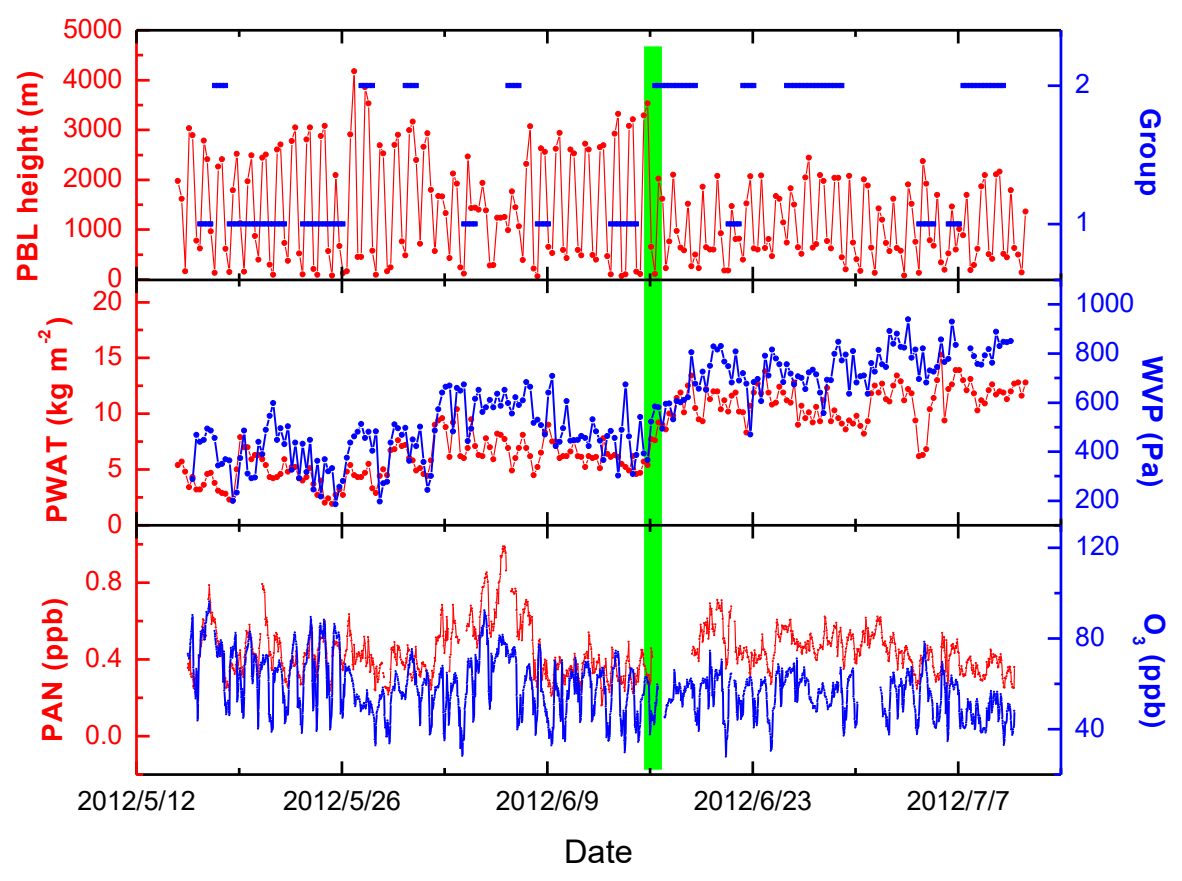

Figure 5. Distributions of two groups of days and time series the PBL height, PWAT (precipitable water of entire atmosphere), WVP (water vapor pressure), PAN and $\mathrm{O}_{3}$. Groups 1 and 2 represent two groups of days with different $\mathrm{O}_{3}$ enhancement $\left(\Delta \mathrm{O}_{3}\right)$ during 05:00-10:00 LT, with Group 1 including 15 days with the greatest $\Delta \mathrm{O}_{3}$ (denoted as High $\Delta \mathrm{O}_{3}$ in Fig. 4) and Group 2 including 15 days with the smallest $\Delta \mathrm{O}_{3}$ (denoted as Low $\Delta \mathrm{O}_{3}$ in Fig. 4). The PBL height and PWAT were acquired from the FNL data with temporal resolution of $6 \mathrm{~h}$. WVP were calculated and processed as $6 \mathrm{~h}$ resolution data from field observations. PAN and $\mathrm{O}_{3}$ concentrations were processed as hourly data.

erably suppressed, and the PWAT and WVP as well as the concentrations of PAN and $\mathrm{O}_{3}$ were significantly enhanced (Fig. 5). In this relatively humid episode, the nighttime concentrations of $\mathrm{PAN}$ and $\mathrm{O}_{3}$ were largely elevated, which may be attributable to the PBL structure and air masses transported from the polluted region (see Sect. 3.5).

In conclusion, the South Asian monsoon brings not only more water vapor over the central Tibet area but also effectively drives the PBL evolution, which plays an important role in shaping the diurnal patterns of PAN and $\mathrm{O}_{3}$ at the NMC site.

\section{4 $\mathrm{O}_{3}$ and PAN abundance under the impact from UTLS}

It is noticeable in Fig. 4 that the levels of daytime $\mathrm{O}_{3}$ were considerably different between the two groups, while those of daytime PAN were close to each other. In the average diurnal curves of $\mathrm{O}_{3}$ and PAN (Fig. 4), the highest hourly $\mathrm{O}_{3}$ levels for Groups 1 and 2 were $69.7 \pm 2.4$ and $59.0 \pm 2.5 \mathrm{ppb}$, and the highest hourly PAN levels were $0.48 \pm 0.02$ and $0.49 \pm 0.05 \mathrm{ppb}$, respectively. Observations at WLG showed that air masses from higher altitudes (i.e., UTLS) contained higher $\mathrm{O}_{3}$ and lower PAN (Xue et al., 2011). As shown in Fig. 5, the daytime PBL in Group 1 could reach much higher altitudes than that in Group 2, indicating a higher probability of downward mixing of $\mathrm{O}_{3}$-rich air from the middle and upper troposphere on the days in Group 1. Therefore, the higher daytime $\mathrm{O}_{3}$ value for Group 1 is qualitatively consistent with the observational results from WLG (Xue et al., 2011). Only a negligible distinction of daytime PAN was found between the two groups, implying that on average, air masses from higher altitudes did not cause lower or higher daytime PAN.

Surface levels of air pollutants at any site depends mainly on local chemistry, transport, and deposition. Since the TP is a pristine and high-altitude region with little emissions of $\mathrm{O}_{3}$ and PAN precursors, local chemistry cannot cause large day-to-day variations in these species, as shown in Ma et al. (2002b). Therefore, a large fluctuation in the daytime levels usually indicates a substantial change of transport contribution, particularly vertical transport. In general, the $\mathrm{O}_{3}$ level increases from the ground to the UTLS. This is also true over the TP and its surrounding areas, as shown by Worden et al. (2009). In some cases, air masses in the UTLS with $\mathrm{O}_{3}$ close to or higher than $100 \mathrm{ppb}$ can be downward transported to near the ground, causing high surface $\mathrm{O}_{3}$ events. Such cases have been often observed at high-altitude sites (Ding and Wang, 2006; Wang et al., 2006; Helmig et al., 2007; Cristofanelli et al., 2010; Lefohn et al., 2012; Ma et al., 2014; Huang et al., 2017; Xu et al., 2018) and occasionally also at some low-altitude sites (e.g., Lefohn et al., 2012). Thus, surface $\mathrm{O}_{3}$ concentrations observed at sites in the TP 


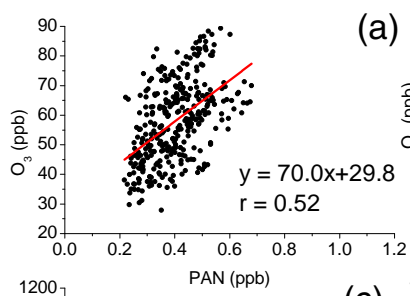

(a)
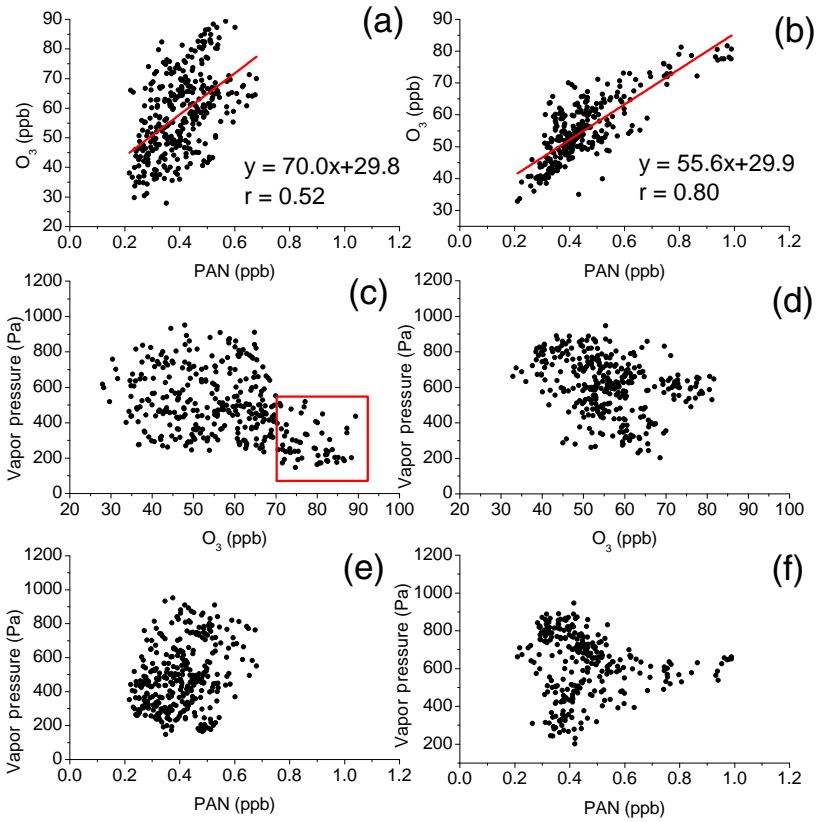

Figure 6. Scatter plots of hourly $\mathrm{O}_{3}$ versus PAN, vapor pressure versus $\mathrm{O}_{3}$, vapor pressure versus PAN of Group $1(\mathbf{a}, \mathbf{c}, \mathbf{e})$ and Group 2 (b, d, f), following Fig. 4. The correlation shown in (a) and (b) are significant at $\alpha=0.01$. The data points within the red rectangle in (c) represent $\mathrm{O}_{3}$ levels higher than $70 \mathrm{ppb}$ and WVP lower than $500 \mathrm{~Pa}$.

region can sometimes be used as an indicator of air masses from the higher altitudes and also reflects the depth of developed PBL. Observations at Summit, Greenland (3212 m a.s.l) showed that air masses from the UTLS always accompanied with high ozone and low water vapor events (Helmig et al., 2007; Huang et al., 2017). As the WVP profile over the TP shows a clear decrease with height (Chen et al., 2013), air masses from high altitudes over the TP can also be indicated by lower WVP.

To gain more insight into air masses from upper origins, we attempt to differentiate air masses originated in the upper troposphere from other air masses. Following the grouping of days in Sect. 3.3, scatter plots of $\mathrm{O}_{3}-\mathrm{PAN}, \mathrm{WVP}-\mathrm{O}_{3}$, and WVP-PAN are shown in Fig. 6 for the two groups. The data points within the red rectangle in Fig. 6c are measurements associated with higher $\mathrm{O}_{3}$ levels and lower WVP. We consider these as measurements with significant features of middle/upper tropospheric air since they are above the highest average hourly $\mathrm{O}_{3}$ level $(69.7 \mathrm{ppb})$ shown in Fig. $4 \mathrm{~b}$ and associated with $\mathrm{WVP}<500 \mathrm{~Pa}$. Figure $6 \mathrm{~b}$ displays a good positive $\mathrm{O}_{3}$-PAN correlation for Group 2, which is consistent with simultaneous photochemical production of both secondary pollutants. However, the dataset from Group 1 shows a much weaker $\mathrm{O}_{3}$-PAN correlation (Fig. 6a), indicating a weaker relationship between PAN and $\mathrm{O}_{3}$ in Group 1. Nearly no correlation between PAN and WVP is found (Fig. 6e). At present, the actual causes of the poor $\mathrm{O}_{3}-\mathrm{PAN}$ and WVPPAN correlations are unknown. However, it is reasonable to believe that on the days in Group 1, the observed $\mathrm{O}_{3}$ level was more influenced by air masses from the UTLS, where the $\mathrm{O}_{3}$ level is higher and the PAN level lower than at the surface (Worden et al., 2009; Moore and Remedios, 2010). In addition, it is suspected that the horizontal variability in PAN was larger than that of $\mathrm{O}_{3}$ during our observations.

Figure 6 does not allow for an estimate of PAN abundance in upper levels. However, we can make use of some cases with deep convection and apparent downward transport activities in the dry period. Here we try to deduce the origins of air masses in two cases and roughly estimate the PAN concentrations associated with air masses from upper levels. The two cases chosen for analysis are 25 May 2012 and 24 August 2011. Figure 7 displays the vertical velocity (omega, $\omega$ ) fields and horizontal wind vectors at different times and air pressure levels, with the two cases being labeled with black rectangles (termed as Case 1 and Case 2). Positive and negative $\omega$ values indicate descending and ascending, respectively. Both cases were from dry periods, when the PBL could reach higher heights and favor the entrainment of upper air masses.

Figure 7a shows that positive $\omega$ dominated the PBL from early 25 to early 26 May 2012 (Case 1), with the range of higher $\omega\left(>0.1 \mathrm{hPa} \mathrm{s}^{-1}\right)$ extending from surface to $350 \mathrm{hPa}$, and a distinct valley of specific humidity line of $2 \mathrm{~g} \mathrm{~kg}^{-1}$, indicating a strong downward transport. In response to this downward transport, PAN and $\mathrm{O}_{3}$ were both elevated to higher levels and WVP decreased to about $200 \mathrm{~Pa}$ (Fig. 5). A similar case occurred during 22-23 August 2011 (Case 2), as shown in Fig. 7b. On 22 August, the height with descending air extended from the ground up to $300 \mathrm{hPa}$ and lasted all day long, with very high intensity $\left(\omega>0.3 \mathrm{hPa} \mathrm{s}^{-1}\right)$. For better understanding of Case 2, we display in Fig. 8 the time series of $\mathrm{O}_{3}$, PAN, and related meteorological parameters during 16-25 August 2011. The $\mathrm{O}_{3}$ and PAN levels increased rapidly on 22 August 2011, as indicated by the blue arrow in Fig. 8b. In parallel with the increases of $\mathrm{O}_{3}$ and PAN levels, relative humidity and wind vector changed rapidly, with the former dropping dramatically from 80 to about $30 \%$ and the later turning from southerly to northerly. Similar rapid variations were also observed partly during 23-24 August 2011, corresponding to the subsiding of dry air masses (Fig. 7b).

It is noticeable that the daytime levels of $\mathrm{O}_{3}$ and PAN did not show much distinction among the days from 22 to 24 August 2011. This suggests that the air masses arriving at our site during the period might originate from similar height and area. To prove this, we calculated backward trajectories with endpoints at 500 and $1500 \mathrm{~m}$ above the ground of the NMC site. Some of the trajectories for the two selected cases, 25 May 2012 (Case 1) and 22 August 2011 (Case 2), are plotted in Figs. 9 and 10, respectively, overlaying on the $350 \mathrm{hPa}$ potential vorticity (PV) fields at three time points during 23 
(a)

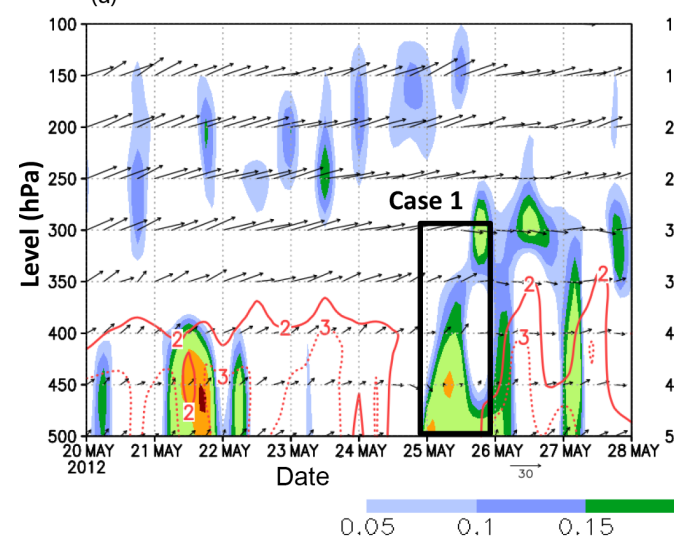

(b)

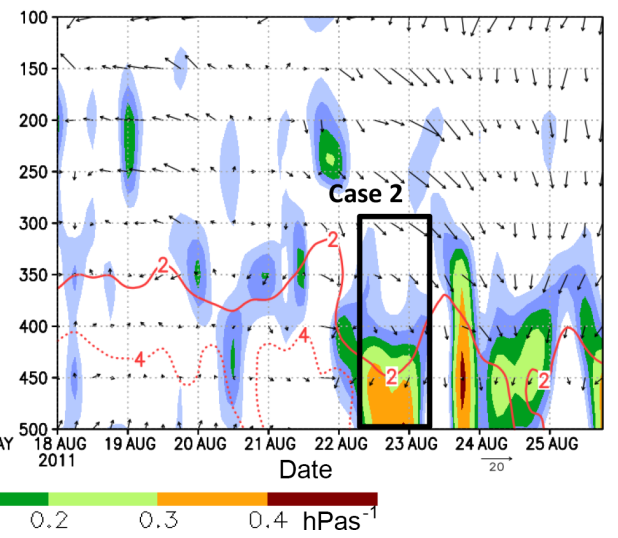

Figure 7. Vertical velocity in pressure coordinates, $\omega$, (shaded), specific humidity (red lines) and horizontal wind field (arrows) in dependence of time and height in two time frames. (a) From 20 to 28 May 2012; (b) From 18 to 25 August 2011. Case 1 and Case 2 correspond to two significant downdraft events.

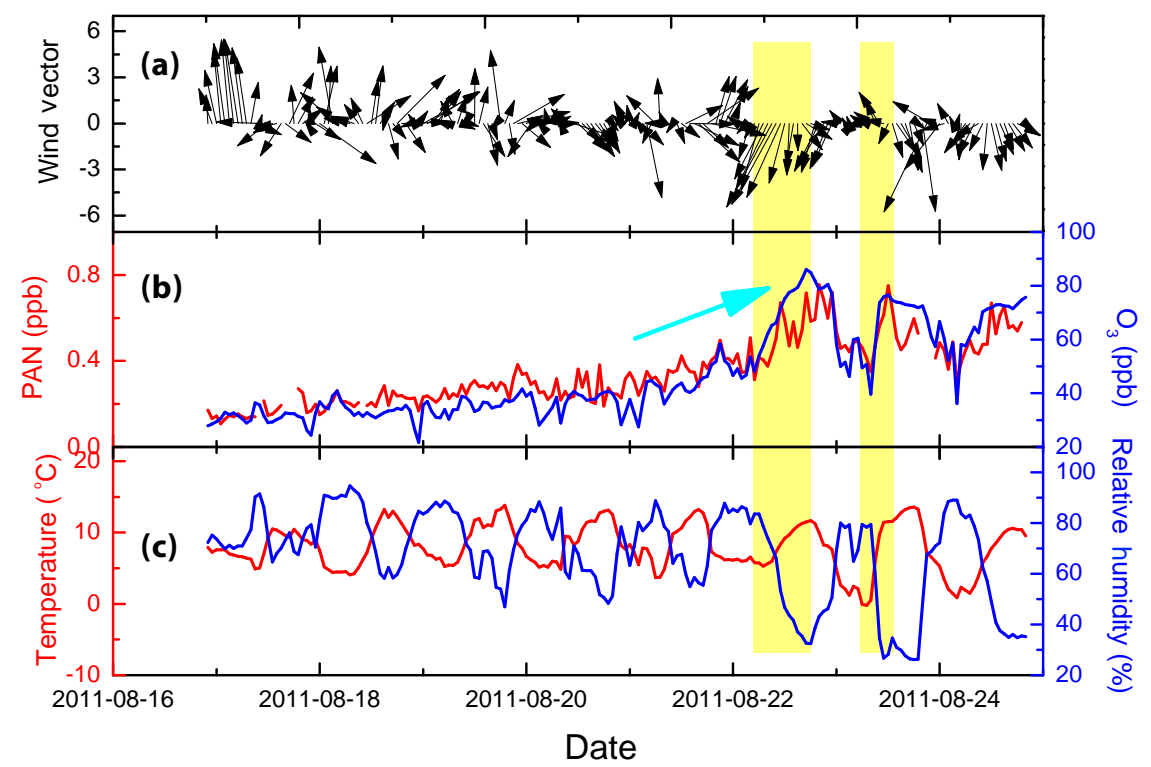

Figure 8. Time series of (a) surface wind vectors, (b) PAN and $\mathrm{O}_{3}$, and (c) temperature and relative humidity during 17-24 August 2011. Yellow bars represent the short periods controlled by downward motion. The blue arrow indicates the increasing trend of $\mathrm{PAN}_{\mathrm{N}} \mathrm{and} \mathrm{O}_{3}$.

24 May 2012 (for Case 1) and during 20-22 August 2011 (for Case 2), respectively. Similar plots with the same trajectories and $250 \mathrm{hPa}$ PV fields are shown in Figs. S2 and S3 for Case 1 and Case 2, respectively. In both cases, stratospheric intrusions occurred as indicated by the higher PV values ( $>2$ ). In Case 1 (Figs. 9 and S2), higher PV covered the zone from $30^{\circ} \mathrm{N}$ to beyond $50^{\circ} \mathrm{N}$. In Case 2 (Figs. 10 and S3), higher PV extended from about $40^{\circ} \mathrm{N}$ to beyond $50^{\circ} \mathrm{N}$. In both cases air masses arriving at the NMC site originated from or traveled through the zones between 350 and $250 \mathrm{hPa}$ that were obviously impacted by stratospheric intrusions. Therefore, the PAN and $\mathrm{O}_{3}$ measurements in both cases were influenced by air masses from the UTLS. In ad- dition to the transport feature, the elevated $\mathrm{O}_{3}$ and decreased water vapor amount in surface air also indicate impacts of high-level air masses. For Case 1 and Case 2, the PAN level was elevated respectively up to 0.52 and $0.72 \mathrm{ppb}$, which can be regarded as the maximum PAN levels observed under the impact from UTLS.

\subsection{A PAN episode driven by the South Asian monsoon}

In a warm environment, PAN is short lived. Below $7 \mathrm{~km}$, thermal decomposition is the main loss process of PAN (Talukdar et al., 1995). Thus, although polluted air masses from south of the Himalayas can be transported to the TP along 


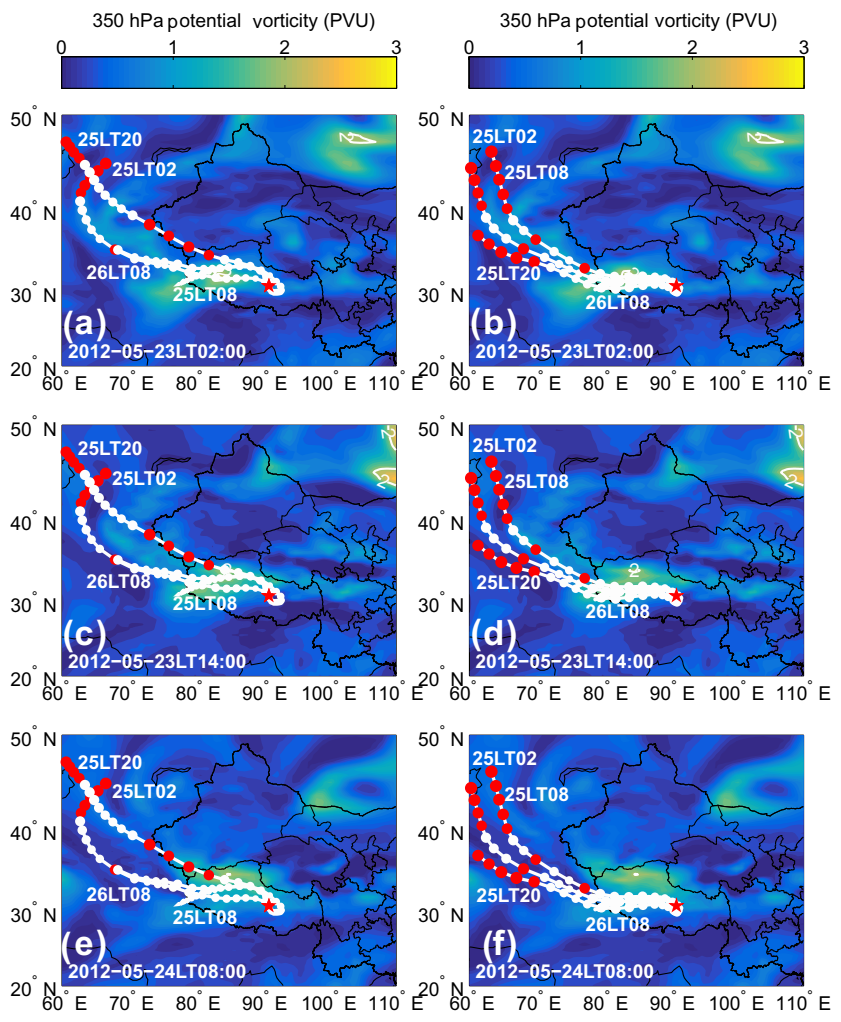

Figure 9. The $350 \mathrm{hPa}$ potential vorticity fields at three time-points during 23-24 May 2012 and back trajectories of air masses arriving at $500 \mathrm{~m}(\mathbf{a}, \mathbf{c}, \mathbf{e})$ and $1500 \mathrm{~m}(\mathbf{b}, \mathbf{d}, \mathbf{f})$ above the ground of NMC (red star) during 25-26 May 2012.

the monsoon stream, PAN in the air masses may experience significant loss during traveling. Cox and Roffey (1977) estimated the lifetime of PAN at $25{ }^{\circ} \mathrm{C}$ to be about 2.7 and $0.7 \mathrm{~h}$ for urban and rural daytime conditions, respectively, and that at $15^{\circ} \mathrm{C}$ a factor of 4 longer. During our observations in summer 2012, surface air temperature at NMC varied from -0.5 to $19.4^{\circ} \mathrm{C}$, with an average of $8.4^{\circ} \mathrm{C}$. Thermal decomposition should be much slower under such temperature conditions and only important during warmer daytime periods. However, thermal decomposition might still have removed a significant fraction of PAN during the long-range transport, particularly over the warm low-elevation areas. The level of PAN observed at our site was the remaining PAN in the air masses, which should be significantly lower than that in the formation area. Nevertheless, PAN episodes were observed under certain meteorological conditions. One such episode occurred in early June 2012. As can be seen in Fig. 5, the PAN level peaked during 1-6 June 2012. The maximum PAN level reached $1.0 \mathrm{ppb}$, and the diurnal minima on these days were even higher than the diurnal maxima on many other observation days. The origin of the high PAN levels deserves investigation.

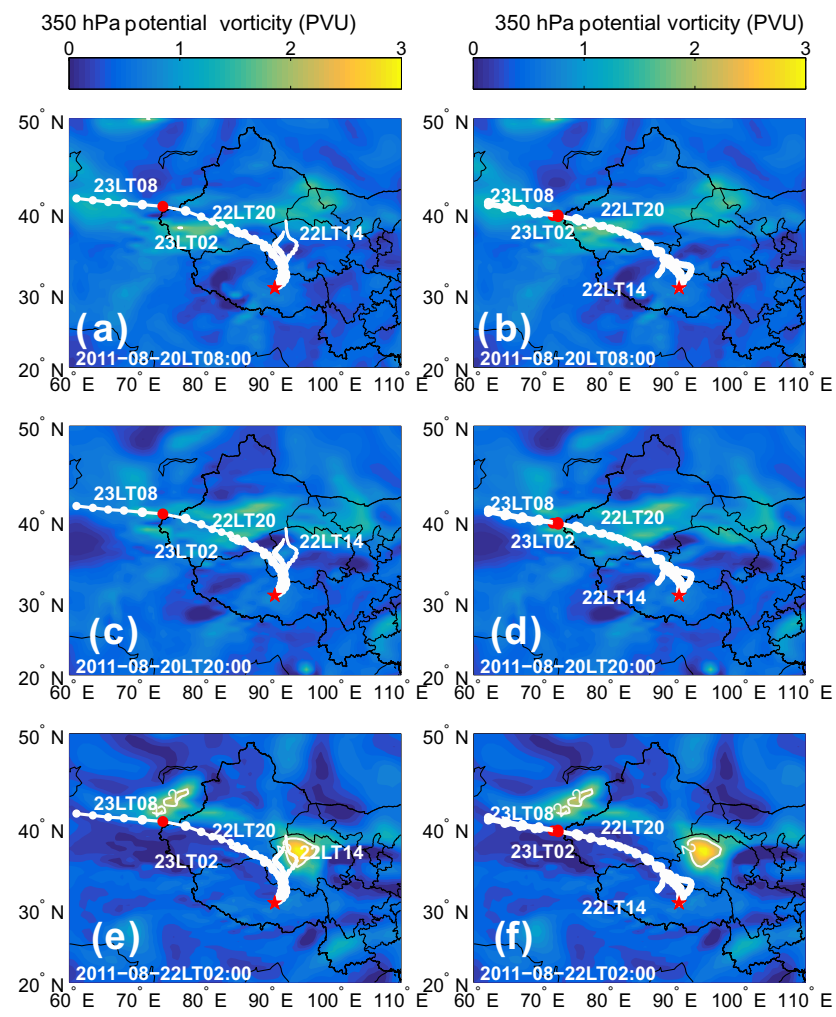

Figure 10. Same as Fig. 9, but for 22-23 August 2011.

Data in Fig. 5 indicate that the monsoon flow prevailed persistently after the middle of June 2012, and there were also some features of monsoon impact during 1-6 June 2012 when the PAN level was increased to near $1 \mathrm{ppb}$. After this abrupt rising, PAN dropped down to a much lower level, suggesting a substantial change in air mass. To understand this phenomenon, we calculated average fields of wind, relative humidity, and $\omega$ at sigma $=0.995$ for the periods 30-31 May using the FNL reanalysis data. During 30-31 May 2012, the major part of the Indian subcontinent was controlled by an anticyclone system and a large convergence zone formed over the central TP (see Fig. S4). The NMC site was within this convergence zone and obviously influenced by airflow from north India. Figure 11 shows the average wind fields for 12:00 (UTC) for 4, 5, 7, and 8 June 2012. These wind fields give a clue to the origin of the high level of PAN observed during 1-6 June 2012. As indicated by the wind fields in Figs. 11 and S4, after 30 May the NMC site was influenced by westerly and southwesterly winds, which could transport air masses from South Asia to the NMC site. After this period, the site was influenced by significantly different air masses. For example, the average wind fields shown in Fig. 11c and d indicate that after 7 June 2012, strong southerly and southeasterly winds developed over east India and southeast Nepal, and southerly wind prevailed over the area surrounding $\mathrm{NMC}$, which promoted the transport of air 

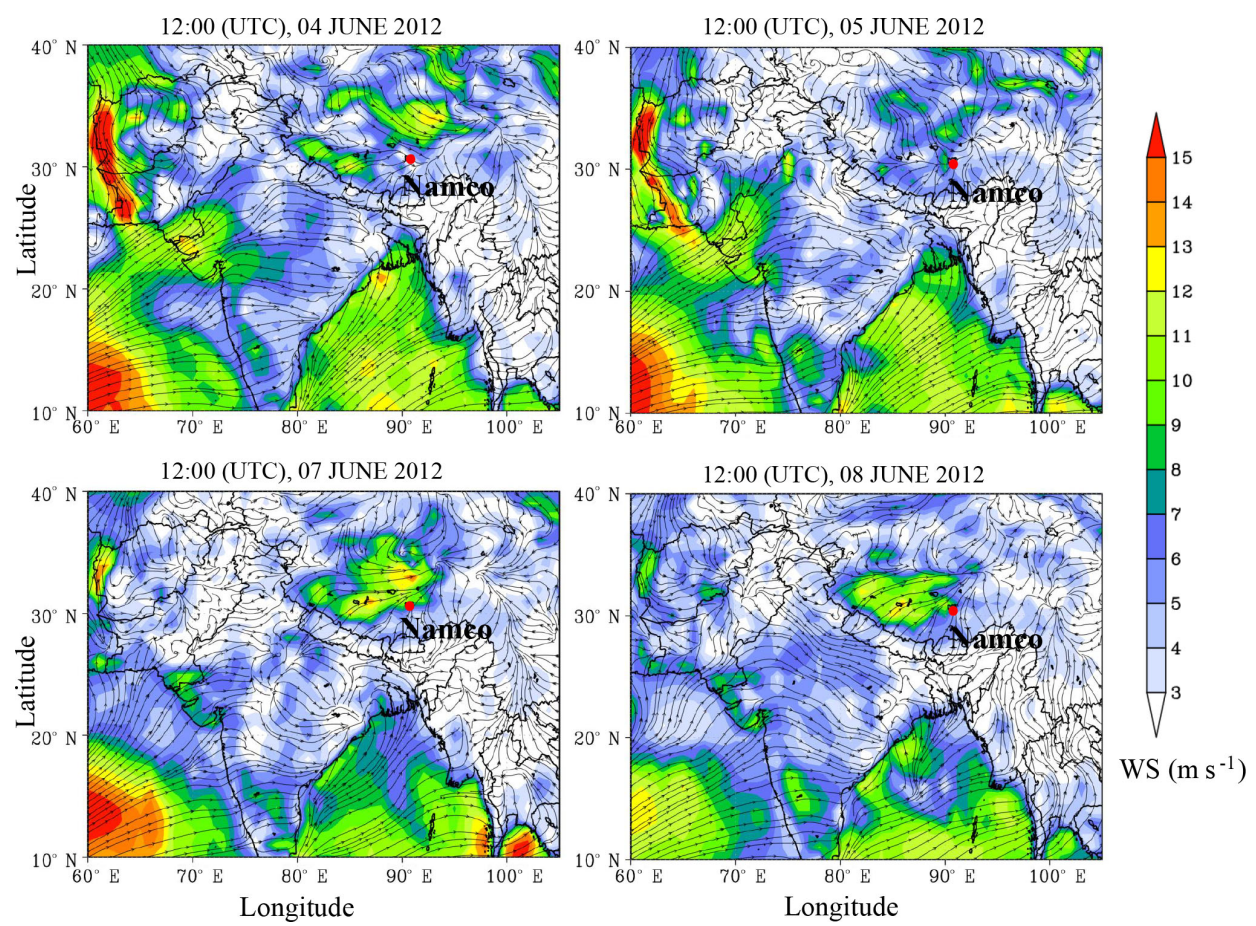

Figure 11. Average fields of wind at sigma $=0.995$ for 12:00 (UTC) for 4, 5, 7, and 8 June 2012 .

masses from the Bay of Bengal. Although most of the central and western TP was within the convergence zone, NMC and its surrounding were outside of its direct impact. Such change in air masses arriving at NMC inevitably caused substantial differences in photochemistry.

Northern India suffers photochemical pollution, as indicated by observations of high levels of surface $\mathrm{O}_{3}$ (Ghude et al., 2008) and tropospheric $\mathrm{O}_{3}$ (Fishman et al., 2003). Emission inventories (Ohara et al., 2007; Q. Zhang et al., 2009) indicate that north India is one of the Asian emission centers for pollutants including $\mathrm{NO}_{x}$ and VOCs. In addition to anthropogenic sources, biomass burning is also an important source for PAN, and some of the biomass burning plumes can penetrate the boundary layer and cause PAN formation over a large area (Tereszchuk et al., 2013; Fischer et al., 2014; Zhu et al., 2015). Figure S5 shows tropospheric $\mathrm{NO}_{2}$ and $\mathrm{HCHO}$ columns, together with maps of fire spots for 1-3 and 4-6 June 2012. As can be seen in this figure, $\mathrm{NO}_{2}$ and $\mathrm{HCHO}$ in the troposphere over north India and north Pakistan were highly abundant during both periods. However, the $\mathrm{NO}_{2}$ and HCHO levels were obviously higher during 1-3 June than during 4-6 June. The differences in $\mathrm{NO}_{2}$ and $\mathrm{HCHO}$ levels might have been caused by open biomass burning since much more fire spots were observed during 1-3 June than during 4-6 June (see Fig. S5e and f). The high tropospheric $\mathrm{NO}_{2}$ and $\mathrm{HCHO}$ columns suggest the presence of high concentrations of $\mathrm{NO}_{x}$ and VOCs, which may lead to rapid formation of $\mathrm{O}_{3}$ and PAN under the summer conditions over the South Asian region. Since this region borders on the TP, it is likely that
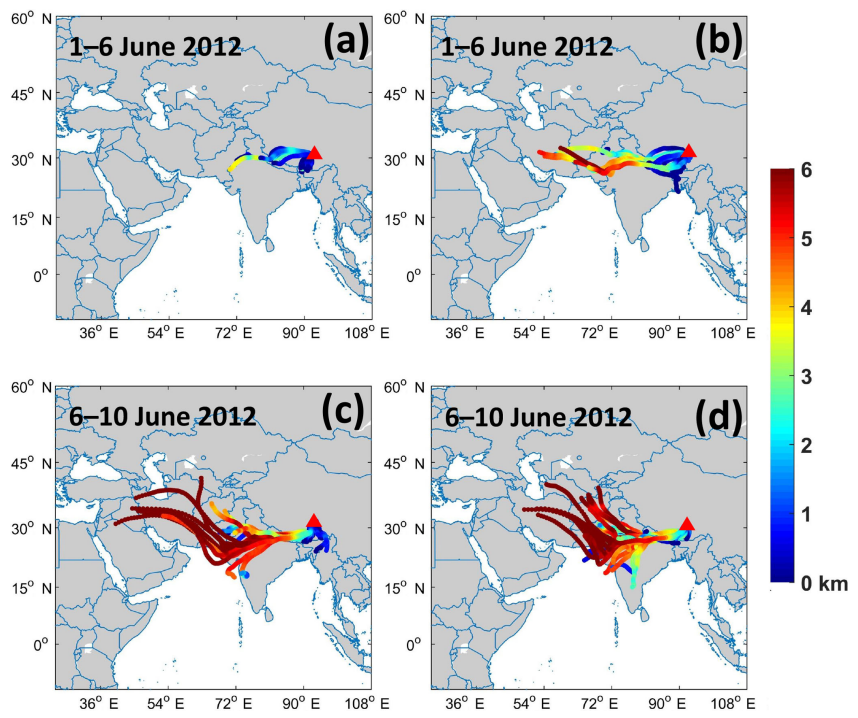

Figure 12. Backward air trajectories arriving at NMC with endpoint heights of $500 \mathrm{~m}(\mathbf{a}, \mathbf{c})$ and $1500 \mathrm{~m}(\mathbf{b}, \mathbf{d})$ for the periods 16 June 2012 (a, b) and 6-10 June 2012 (c, d). The color scale shows trajectory heights in $\mathrm{km}$ above ground level.

the PAN episode observed at our site during 1-6 June 2012 was mainly caused by long-range transport of plumes with high PAN and its precursors from South Asia.

To further support the above view, we made calculations of backward air trajectories. The results are presented in Fig. 12. The 5-day trajectories were calculated for endpoints at 500 
and $1000 \mathrm{~m}$ above ground for 1-6 and 6-10 June 2012, respectively. Obviously, air trajectories arriving at NMC during 1-6 June were quite different from those during 6-10 June, particularly those with endpoints at $500 \mathrm{~m}$ (Fig. 12a and c). About a half of the trajectories during 1-6 June originated from or moved through the PBL over north India (Fig. 12a), while nearly none of the trajectories during 6-10 June had an opportunity to pass through the PBL over north India (Fig. 12c). Most of the trajectories during 6-10 June originated either from the free troposphere over western Asia and the Indian subcontinent or from the PBL south of NMC. Forward trajectories were also calculated for air masses originated from matrices of locations in the domains west and south of the NMC site. Examples of forward trajectories matrices are shown in Fig. S6 for trajectories starting at 06:00 UTC, 3 June 2012, and 08:00 UTC, 8 June 2012. The trajectories clearly indicate that the NMC site was impacted by air masses from different areas before and after 6 June. Around 4-5 June 2012, NMC was mainly impacted by air masses from the SW-W sector (north India, north Pakistan, and Nepal). Around 9-10 June, however, NMC was mainly impacted by air masses from the S-SW sector (Bangladesh, Bhutan, etc.). These results are consistent with those from the backward trajectories in Fig. 12. On the one hand, the above analysis can explain the sudden decrease in the PAN level after 6 June 2012, and on the other hand support the idea that the PAN episode observed during 1-6 June 2012 was mainly caused by plumes from north India, north Pakistan, and Nepal.

Although the TP is one of the cleanest regions of the world, transport of anthropogenic pollutant to this region deserves attention. Some recent studies have showed that air pollutants can be transported to the Himalayas or to the TP region through passes like river valleys from the surroundings (Cong et al., 2007, 2009; Bonasoni et al., 2010; Kopacz et al., 2011; Lüthi et al., 2015; Shen et al., 2015; Zhang et al., 2015). The main source regions are South Asia and East Asia. During the South Asian monsoon, the TP is predominately influenced by air masses from the Indian subcontinent. Impacts of transported pollutants on atmospheric environment over the Himalayas and TP, particularly the climate and hydrological effects of deposition of black carbon and other substances on Himalayan glaciers, have caused concerns (Ramanathan et al., 2007; Ming et al., 2012; Zhao et al., 2013; Qu et al., 2014; Wang et al., 2015; Zhang et al., 2015).

So far, studies of pollutant transport to the TP and its effects have focused on aerosols (compositions and optical depth) and less attention has been paid to the transport of gaseous pollutants. There has been no previous report about impacts of long-range transport of pollutants on tropospheric photochemistry over the central TP region. Our results show, for the first time, that long-range transport of polluted air masses from north India and other South Asian areas can significantly enhance ambient levels of PAN at NMC. Although we have no observational data of PAN from other sites in the $\mathrm{TP}$, it is likely that the entire convergence zone in the central and western TP (Figs. 11 and S4) was more or less impacted by the pollutants from South Asia. This implies that photochemistry over a large area in the TP was probably disturbed for at least 10 days in the cases shown in Figs. 11 and S4. PAN transported to the TP region may be thermally and/or photolytically decomposed to release $\mathrm{NO}_{x}$, acting as a chemical source of atmospheric $\mathrm{NO}_{x}$ over the TP, a region with very little anthropogenic emission of $\mathrm{NO}_{x}$. The impacts of the transport of PAN and other related species on tropospheric photochemistry over the TP need to be studied in the future.

\subsection{PAN levels at different heights over the TP}

In addition to this study, in situ PAN measurements from the TP are only reported by Xue et al. (2011). As PAN is a key source of $\mathrm{NO}_{x}$ in remote regions, its concentration and distribution are important for understanding the photochemistry over regions like the TP. Here we provide a collection of PAN data for the TP region.

Table 1 summarizes the PAN data available for the TP from in situ observations, satellite and space shuttle observations, and model simulations. Based on our in situ observations at NMC $(4.7 \mathrm{~km})$, we obtained an averaged PAN level of $0.36 \mathrm{ppb}$ for 17-24 August 2011 and $0.44 \mathrm{ppb}$ for 15 May13 July 2012. In situ observations at WLG (3.8 km a.s.1.) found an average PAN level of $0.44 \mathrm{ppb}$ for the period from 22 July to 16 August 2006 (Xue et al., 2011). The limited in situ observations in the surface layer do not show substantial spatial and temporal differences in the average level of PAN. However, the PAN level did show significant increases in some cases with obvious transport impacts from the UTLS (e.g., 22 August 2011) and from South Asia (e.g., 1-6 June 2012).

Developments in remote sensing have made it possible to detect global PAN in the UTLS from space. During 913 August 1997, observations using the CRyogenic Infrared Spectrometers and Telescopes for the Atmosphere (CRISTA) aboard the space shuttle showed PAN levels in the range of 0.1-0.2 ppb for $18 \mathrm{~km}$ over the TP (Ungermann et al., 2016). Based on the retrievals of satellite observations using the Michelson Interferometer for Passive Atmospheric Sounding (MIPAS), the average PAN levels in March 2003 were in the ranges of $0.15-0.23 \mathrm{ppb}$ for $234 \mathrm{hPa}$ and $0.35-0.45 \mathrm{ppb}$ for $333 \mathrm{hPa}$ over the TP, and those in August 2003 in the ranges of $0.15-0.23 \mathrm{ppb}$ for $185 \mathrm{hPa}$ and $0.35-0.50 \mathrm{ppb}$ for $278 \mathrm{hPa}$ (Moore and Remedios, 2010). The PAN level at $12 \mathrm{~km}$ over TP was about $0.10-0.15 \mathrm{ppb}$ in October 2007 (Wiegele et al., 2012), which is very close to the range $(0.1-0.2 \mathrm{ppb})$ on 21 October 2003 (Glatthor et al., 2007). Results from the model simulations by Fischer et al. (2014) show that the PAN level during June-August 2008 varied in the range of 0.3 $0.5 \mathrm{ppb}$ in the $2-6 \mathrm{~km}$ layer and $0.2-0.4 \mathrm{ppb}$ in the $6-10 \mathrm{~km}$ 
Table 1. Measured and modeled PAN at different heights over the TP.

\begin{tabular}{|c|c|c|c|c|}
\hline PAN (ppb) & Period & Height $^{\mathrm{a}}$ & Method & Reference \\
\hline $0.35(0.11-0.76)^{\mathrm{b}}$ & 17-24 August 2011 & $4.7 \mathrm{~km}$ & ground measurements & \\
\hline $0.44(0.21-0.99)^{\mathrm{b}}$ & 15 May-13 July 2012 & $4.7 \mathrm{~km}$ & ground measurements & \\
\hline $0.52(0.31-0.72)^{\mathrm{b}}$ & 22 August 2011 & $4.7 \mathrm{~km}$ & ground measurements with impact from the UT & this work \\
\hline $0.40(0.24-0.50)^{\mathrm{b}}$ & 25 May 2012 & $4.7 \mathrm{~km}$ & ground measurements with impact from the UT & \\
\hline $0.62(0.27-0.99)^{\mathrm{b}}$ & 1-6 June 2012 & $4.7 \mathrm{~km}$ & ground measurements with impact from South Asia & \\
\hline $0.44(0.14)^{\mathrm{c}}$ & 22 July-16 August 2006 & $3.8 \mathrm{~km}$ & ground measurements & Xue et al. (2011) \\
\hline $0.35-0.45^{d}$ & & $333 \mathrm{hPa}$ & MIPAS & Moore and Remedios (2010) \\
\hline $0.15-0.23^{\mathrm{d}}$ & March 2003 & $234 \mathrm{hPa}$ & MIPAS & \\
\hline $0.35-0.5^{\mathrm{d}}$ & & $278 \mathrm{hPa}$ & MIPAS & \\
\hline $0.15-0.23^{\mathrm{d}}$ & August 2003 & $185 \mathrm{hPa}$ & MIPAS & \\
\hline $0.1-0.15^{\mathrm{d}}$ & October 2007 & $12 \mathrm{~km}$ & MIPAS & Wiegele et al. (2012) \\
\hline $0.1-0.2^{\mathrm{d}}$ & 21 October 2003 & $12 \mathrm{~km}$ & MIPAS & Glatthor et al. (2007) \\
\hline $0.1-0.2^{\mathrm{d}}$ & 9-13 August 1997 & $18 \mathrm{~km}$ & space shuttle experiment CRISTA-2 & Ungermann et al. (2016) \\
\hline $\begin{array}{l}0.3-0.5^{\mathrm{d}} \\
0.2-0.4^{\mathrm{d}}\end{array}$ & June-August 2008 & $\begin{array}{l}2-6 \mathrm{~km} \\
6-10 \mathrm{~km}\end{array}$ & $\begin{array}{l}\text { GEOS-Chem modeling } \\
\text { GEOS-Chem simulation }\end{array}$ & Fischer et al. (2014) \\
\hline $0.15-0.2^{\mathrm{d}}$ & June-September 1995-2004 & $6-10 \mathrm{~km}$ & ECHAM5-HAMMOZ model simulation & Fadnavis et al. (2014) \\
\hline
\end{tabular}

${ }^{\mathrm{a}}$ Either elevation above the sea level or air pressure layer. ${ }^{\mathrm{b}}$ Overall average with the range of hourly mean. ${ }^{\mathrm{c}}$ Overall average with standard deviation. ${ }^{\mathrm{d}}$ Reading based on the color scale given in the reference.

layer over the TP. Another model simulation study (Fadnavis et al., 2014) obtained a PAN range of 0.15-0.2 ppb for the 6-10 km layer and for June-September 1995-2004.

The satellite measurements and simulation results listed in Table 1 indicate a general decrease in PAN level from the upper troposphere to the lower stratosphere, consistent with the vertical distribution of PAN in the UTLS (Pope et al., 2016). These data represent PAN levels averaged over larger scales for certain periods. In situ measurements on the ground show average PAN levels very close to $333 \mathrm{hPa}$ (about $10 \mathrm{~km}$ ) values. So far, there has been no observation of the vertical distribution of PAN in the middle and lower troposphere over the TP. Based on the results from the case studies in Sect. 3.4 and 3.5, we believe the PAN levels in middle and lower tropospheric air over the TP may be more variable and sometimes elevated by transport of plumes from anthropogenic and biomass burning emissions. The significance of the transport impact deserves systematic study, which is out the scope of this work.

\section{Conclusions}

For the first time, we made simultaneous ground-based measurements of two photochemical products, PAN and $\mathrm{O}_{3}$ at Nam Co, a remote site in the central Tibetan Plateau (TP) region. Our effective PAN data cover two summer periods, i.e., from 17 to 24 August 2011 and from 15 May to 13 July 2012. The average levels of PAN were $0.36 \mathrm{ppb}$ (range: $0.11-$ $0.76 \mathrm{ppb}$ ) and $0.44 \mathrm{ppb}$ (range: $0.21-0.99 \mathrm{ppb}$ ) in the 2011 and 2012 periods, respectively. During the observation in 2012, the $\mathrm{O}_{3}$ level varied from 27.9 to $96.4 \mathrm{ppb}$, with an average of $60.0 \mathrm{ppb}$, very close to the summertime $\mathrm{O}_{3}$ level found at Waliguan, a global baseline station at the northeastern edge of the TP.

PAN and $\mathrm{O}_{3}$ showed profound and similar diurnal cycles, with valleys around 05:00 LT, steep rises in the early morning, and broader platforms of high values during 09:0020:00 LT. Such patterns of diurnal variations in both gases, particularly the sharp increases even before sunrise, cannot be attributed solely to local photochemistry. Our analysis suggests that the PBL evolution played a key role in shaping the diurnal patterns of both gases. PAN and $\mathrm{O}_{3}$ in the shallow nocturnal PBL were significantly removed by their sinks, such as chemical reactions and dry deposition. In the early morning, the elevation of the PBL height caused downward mixing of upper air containing higher PAN and $\mathrm{O}_{3}$, leading to steep rises of the concentrations of these gases. The downward mixing and photochemistry sustained the higher levels of PAN and $\mathrm{O}_{3}$ in the daytime. However, there were day-to-day differences in the PBL evolution, which could cause large differences in the diurnal variations in PAN and $\mathrm{O}_{3}$. We identified two groups of days with different meteorological conditions and different diurnal patterns of trace gases and meteorological parameters. Days in Group 1 were mainly distributed in the pre-monsoon period, with higher daytime height of PBL (about $3 \mathrm{~km}$ ), lower humidity, and larger day-night variations in $\mathrm{PAN}$ and $\mathrm{O}_{3}$. Days in Group 2 were mainly distributed in the monsoon period, with shallower daytime PBL (about $2 \mathrm{~km}$ ), higher humidity, and much smaller day-night variations in $\mathrm{PAN}$ and $\mathrm{O}_{3}$.

There were some cases with obvious rapid transport of air masses during our observations. We identified two cases of rapid downward transport of air masses from the UTLS. The observed maximum PAN levels during these two cases ranged from 0.5 to $0.7 \mathrm{ppb}$. These PAN levels are higher than those retrieved from satellite measurements for the UTLS. 
Therefore, it is likely that the tropospheric PAN over the TP may be disturbed for short periods, which is not easily captured by satellite observation. In addition to vertical transport of PAN, we also identified a case of strong long-range transport of PAN plumes. During this case, relatively polluted air masses from the PBL over north India, north Pakistan, and Nepal were able to be transported over the western and central TP to NMC, causing a profound episode of PAN with maximum close to $1 \mathrm{ppb}$ during 1-6 June 2012. In contrast, significantly lower PAN levels were observed when air masses originated from other areas. Although transport of aerosols from South and Southeast Asia and its impacts on atmospheric environment over the Himalayas and the TP have been intensively studied in recent years, transport of gaseous pollutants and its impacts have received less attention. Our results show, for the first time, that polluted air masses from South Asia can significantly enhance the ambient level of PAN at NMC. The spatial scale and frequency of this phenomenon and its impacts on tropospheric photochemistry over the TP region remain to be studied in the future.

Data availability. The observational data analyzed in this paper can be made available for scientific purposes by contacting the corresponding author(xiaobin_xu@189.cn).

\section{The Supplement related to this article is available online} at https://doi.org/10.5194/acp-18-5199-2018-supplement.

Competing interests. The authors declare that they have no conflict of interest.

Special issue statement. This article is part of the special issue "Study of ozone, aerosols and radiation over the Tibetan Plateau (SOAR-TP) (ACP/AMT inter-journal SI)". It is not associated with a conference.

Acknowledgements. The authors thank the staff of the Nam Co station and Xizang Meteorological Bureau for logistical support. This work was supported by the China Special Fund for Meteorological Research in the Public Interest (GYHY201106023), the Natural Science Foundation of China (No. 41330422) and Basic Research Fund of CAMS (2011Z003 and 2013Z005)

Edited by: Hang Su

Reviewed by: two anonymous referees

\section{References}

Bonasoni, P., Laj, P., Marinoni, A., Sprenger, M., Angelini, F., Arduini, J., Bonafè, U., Calzolari, F., Colombo, T., Decesari, S., Di Biagio, C., di Sarra, A. G., Evangelisti, F., Duchi, R., Facchini, MC., Fuzzi, S., Gobbi, G. P., Maione, M., Panday, A., Roccato, F., Sellegri, K., Venzac, H., Verza, GP., Villani, P., Vuillermoz, E., and Cristofanelli, P.: Atmospheric Brown Clouds in the Himalayas: first two years of continuous observations at the Nepal Climate Observatory-Pyramid (5079 m), Atmos. Chem. Phys., 10, 7515-7531, https://doi.org/10.5194/acp10-7515-2010, 2010

Chen, B., Xu, X. D., Yang, S., and Zhao, T. L.: Climatological perspectives of air transport from atmospheric boundary layer to tropopause layer over Asian monsoon regions during boreal summer inferred from Lagrangian approach, Atmos. Chem. Phys., 12, 5827-5839, https://doi.org/10.5194/acp-125827-2012, 2012.

Chen, X., An, J. A., Su, Z., Torre, L., Kelder, H., Peet, J., Ma, Y., and Fu, R.: The Deep Atmospheric Boundary Layer and Its Significance to the Stratosphere and Troposphere Exchange over the Tibetan Plateau, PloS One, 8, e56909, https://doi.org/10.1371/journal.pone.0056909, 2013.

Cong, Z. Y., Kang, S. C., Liu, X. D., and Wang, G. F.: Elemental composition of aerosol in the Nam Co region, Tibetan Plateau, during summer monsoon season, Atmos. Environ., 41, 11801187, 2007.

Cong, Z. Y., Kang, S., Smirnov, A., and Holben, B.: Aerosol optical properties at Nam Co, a remote site in central Tibetan Plateau, Atmos. Res., 92, 42-48, 2009.

Cox, R. A. and Roffey, M. J.: Thermal decomposition of peroxyacetylnitrate in the presence of nitric oxide. Environ. Sci. Technol., 11, 900-906, 1977.

Cristofanelli, P., Bracci, A., Sprenger, M., Marinoni, A., BonafÈ, U., Calzolari, F., Duchi, R., Laj, P., Pichon, J. M., Roccato, F., Venzac, H., Vuillermoz, E., and Bonasoni, P.: Tropospheric ozone variations at the Nepal Climate ObservatoryPyramid (Himalayas, $5079 \mathrm{~m}$ a.s.1.) and influence of deep stratospheric intrusion events, Atmos. Chem. Phys., 10, 6537-6549, https://doi.org/10.5194/acp-10-6537-2010, 2010.

Dessler, A. E. and Sherwood, S. C.: Effect of convection on the summertime extratropical lower stratosphere, J. Geophys. Res., 109, D23301-D23310, https://doi.org/10.1029/2004jd005209, 2004.

Ding, A. and Wang, T.: Influence of stratosphere-to-troposphere exchange on the seasonal cycle of surface ozone at Mount Waliguan in western China, Geophys. Res. Lett., 33, L03803, https://doi.org/10.1029/2005GL024760, 2006.

Draxler, R. R. and Hess, G. D.: Description of the HYSPLIT 4 modeling system. NOAA Technical Memorandum, ERLARL-224, NOAA Air Resources Laboratory, Silver Spring, MD. 24, 1997.

Fadnavis, S., Schultz, M. G., Semeniuk, K., Mahajan, A. S., Pozzoli, L., Sonbawne, S., Ghude, S. D., Kiefer, M., and Eckert, E.: Trends in peroxyacetyl nitrate (PAN) in the upper troposphere and lower stratosphere over southern Asia during the summer monsoon season: regional impacts, Atmos. Chem Phys., 14, 12725-12743, https://doi.org/10.5194/acp-14-127252014, 2014.

Fischer, E. V., Jaffe, D. A., Reidmiller, D. R., and Jaegle, L.: Meteorological controls on observed peroxyacetyl nitrate at Mount 
Bachelor during the spring of 2008, J. Geophys. Res., 115, D03302, https://doi.org/10.1029/2009jd012776, 2010.

Fischer, E. V., Jaffe, D. A., and Weatherhead, E. C.: Free tropospheric peroxyacetyl nitrate (PAN) and ozone at Mount Bachelor: potential causes of variability and timescale for trend detection, Atmos. Chem. Phys., 11, 5641-5654, https://doi.org/10.5194/acp-11-5641-2011, 2011.

Fischer, E. V., Jacob, D. J., Yantosca, R. M., Sulprizio, M. P., Millet, D. B., Mao, J., Paulot, F., Singh, H. B., Roiger, A., Ries, L., Talbot, R. W., Dzepina, K., and Pandey Deolal, S.: Atmospheric peroxyacetyl nitrate (PAN): a global budget and source attribution, Atmos. Chem. Phys., 14, 2679-2698, https://doi.org/10.5194/acp-14-2679-2014, 2014.

Fishman, J., Wozniak, A. E., and Creilson, J. K.: Global distribution of tropospheric ozone from satellite measurements using the empirically corrected tropospheric ozone residual technique: Identification of the regional aspects of air pollution, Atmos. Chem. Phys., 3, 893-907, https://doi.org/10.5194/acp-3893-2003, 2003.

Flocke, F. M., Weinheimer, A. J., Swanson, A. L., Roberts, J. M., Schmitt, R., and Shertz, S.: On the measurement of PANs by gas chromatography and electron capture detection, J. Atmos. Chem., 52, 19-43, 2005.

Ford, K. M., Campbell, B. M., Shepson, P. B., Bertman, S. B., Honrath, R. E., Peterson, M., and Dibb, J. E.: Studies of Peroxyacetyl nitrate (PAN) and its interaction with the snowpack at Summit, Greenland, J. Geophys. Res., 107, 4102-4111, 2002.

Fu, R., Hu, Y., Wright, J. S., Jiang, J. H., Dickinson, R. E., Chen, M., Filipiak, M., Read, W. G., Waters, J. W., Wu, D. L., and Affiliations, A.: Short circuit of water vapor and polluted air to the global stratosphere by convective transport over the Tibetan Plateau, P. Natl. Acad. Sci. USA, 103, 5664-5669, https://doi.org/10.1073/pnas.0601584103, 2006.

Gettelman, A. and Kinnison, D. E.: Impact of monsoon circulations on the upper troposphere and lower stratosphere, J. Geophys. Res., 109, D22101-D22114, https://doi.org/10.1029/2004jd004878, 2004.

Ghude, S. D., Jain, S. L., Arya, B. C., Beig, G., Ahammed, Y. N., Kumar, A., and Tyagi, B.: Ozone in ambient air at a tropical megacity, Delhi: characteristics, trends and cumulative ozone exposure indices, J. Atmos. Chem., 60, 237-252, 2008.

Glatthor, N., von Clarmann, T., Fischer, H., Funke, B., Grabowski, U., Höpfner, M., Kellmann, S., Kiefer, M., Linden, A., Milz, M., Steck, T., and Stiller, G. P.: Global peroxyacetyl nitrate (PAN) retrieval in the upper troposphere from limb emission spectra of the Michelson Interferometer for Passive Atmospheric Sounding (MIPAS), Atmos. Chem. Phys., 7, 2775-2787, https://doi.org/10.5194/acp-7-2775-2007, 2007.

Gu, Y., Liao, H., and Bian, J.: Summertime nitrate aerosol in the upper troposphere and lower stratosphere over the Tibetan Plateau and the South Asian summer monsoon region, Atmos. Chem. Phys., 16, 6641-6663, https://doi.org/10.5194/acp-166641-2016, 2016.

Helmig, D., Oltmans, S. J., Morse, T. O., and Dibb, J. E.: What is causing high ozone at Summit, Greenland?, Atmos. Environ., 41, 5031-5043, https://doi.org/10.1016/j.atmosenv.2006.05.084, 2007.

Huang, Y., Wu, S., Kramer, L. J., Helmig, D., and Honrath, R. E.: Surface ozone and its precursors at Summit, Greenland: compari- son between observations and model simulations, Atmos. Chem. Phys., 17, 14661-14674, https://doi.org/10.5194/acp-17-146612017, 2017.

Hudman, R. C., Jacob, D. J., Cooper, O. R., Evans, M. J., Heald, C. L., Park, R. J., Fehsenfeld, F., Flocke, F., Holloway, J., Hübler, G., Kita, K., Koike, M., Kondo, Y., Neuman, A., Nowak, J., Oltmans, S., Parrish, D., Roberts, J. M., and Ryerson, T.: Ozone production in transpacific Asian pollution plumes and implications for ozone air quality in California, J. Geophys. Res., 109, D23S10-D23S23, https://doi.org/10.1029/2004jd004974, 2004.

Kopacz, M., Mauzerall, D. L., Wang, J., Leibensperger, E. M., Henze, D. K., and Singh, K.: Origin and radiative forcing of black carbon transported to the Himalayas and Tibetan Plateau, Atmos. Chem. Phys., 11, 2837-2852, https://doi.org/10.5194/acp-11-2837-2011, 2011.

Kramer, L. J., Helmig, D., Burkhart, J. F., Stohl, A., Oltmans, S., and Honrath, R. E.: Seasonal variability of atmospheric nitrogen oxides and non-methane hydrocarbons at the GEOSummit station, Greenland, Atmos. Chem. Phys., 15, 6827-6849, https://doi.org/10.5194/acp-15-6827-2015, 2015.

LaFranchi, B. W., Wolfe, G. M., Thornton, J. A., Harrold, S. A., Browne, E. C., Min, K. E., Wooldridge, P. J., Gilman, J. B., Kuster, W. C., Goldan, P. D., de Gouw, J. A., McKay, M., Goldstein, A. H., Ren, X., Mao, J., and Cohen, R. C.: Closing the peroxy acetyl nitrate budget: observations of acyl peroxy nitrates (PAN, PPN, and MPAN) during BEARPEX 2007, Atmos. Chem. Phys., 9, 7623-7641, https://doi.org/10.5194/acp-9-7623-2009, 2009.

Law, K. S., Fierli, F., Cairo, F., Schlager, H., Borrmann, S., Streibel, M., Real, E., Kunkel, D., Schiller, C., Ravegnani, F., Ulanovsky, A., D'Amato, F., Viciani, S., and Volk, C. M.: Air mass origins influencing TTL chemical composition over West Africa during 2006 summer monsoon, Atmos. Chem. Phys., 10, 10753-10770, https://doi.org/10.5194/acp-10-10753-2010, 2010.

Lelieveld, J. and Dentener, F. J.: What controls tropospheric ozone?, J. Geophys. Res., 105, 3531-3551, 2000.

Lelieveld, J., Brühl, C., JÖckel, P., Steil, B., Crutzen, P. J., Fischer, H., Giorgetta, M. A., Hoor, P., Lawrence, M. G., Sausen, R., and Tost, H.: Stratospheric dryness: model simulations and satellite observations, Atmos. Chem. Phys., 7, 1313-1332, https://doi.org/10.5194/acp-7-1313-2007, 2007.

Lefohn, A. S., Wernli, H., Shadwick, D., Oltmans, S. J., and Shapiro, M.: Quantifying the importance of stratospherictropospheric transport on surface ozone concentrations at highand low-elevation monitoring sites in the United States, Atmos. Environ., 62, 646-656, 2012.

Li, M., Ma, Y., Ma, W., Ishiakawa, H., Sun, F., and Ogino, S.: Structural difference of atmospheric boundary layer between dry and rainy seasons over the central Tibetan Plateau, Journal of Glaciology and Geocryology, 33, 72-79, 2011 (in Chinese).

Lin, W., Xu, X., Zheng, X., Jaxi, D., and Ciren, B.: Two-year measurements of surface ozone at Dangxiong, a remote highland site in the Tibetan Plateau, J. Environ. Sci., 31, 133-145, 2015.

Lüthi, Z. L., Škerlak, B., Kim, S.-W., Lauer, A., Mues, A., Rupakheti, M., and Kang, S.: Atmospheric brown clouds reach the Tibetan Plateau by crossing the Himalayas, Atmos. Chem. Phys., 15, 6007-6021, https://doi.org/10.5194/acp-156007-2015, 2015. 
Ma, J., Liu, H., and Hauglustaine, D.: Summertime tropospheric ozone over China simulated with a regional chemical transport model 1. Model description and evaluation, J. Geophys. Res., 107, ACH 27-21-ACH 27-13, https://doi.org/10.1029/2001JD001354, 2002a.

Ma, J., Tang, J., Zhou, X., and Zhang, X.: Estimates of the Chemical Budget for Ozone at Waliguan Observatory, J. Atmos. Chem., 41, 21-48, https://doi.org/10.1023/A:1013892308983, 2002b.

Ma, Y., Fan, S., Ishikawa, H., Tsukamoto, O., Yao, T., Koike, T., Zuo, H., Hu, Z., and Su, Z.: Diurnal and inter-monthly variation of land surface heat fluxes over the central Tibetan Plateau area, Theor. Appl. Climatol., 80, 259-273, 2005.

Ma, J., Lin, W. L., Zheng, X. D., Xu, X. B., Li, Z., and Yang, L. L.: Influence of air mass downward transport on the variability of surface ozone at Xianggelila Regional Atmosphere Background Station, southwest China, Atmos. Chem. Phys., 14, 5311-5325, https://doi.org/10.5194/acp-14-5311-2014, 2014.

Ma, W., Ma, Y., and Bob, S.: Feasibility of Retrieving Land Surface Heat Fluxes from ASTER Data Using SEBS: a Case Study from the NamCo Area of the Tibetan Plateau, Arct. Antarct. Alp. Res., 43, 239-245, 2011.

Ming, J., Du, Z., Xiao, C., Xu, X., and Zhang, D.: Darkening of the mid-Himalaya glaciers since 2000 and the potential causes, Environ. Res. Lett., 7, 014021, https://doi.org/10.1088/17489326/7/1/014021, 2012.

Moore, D. P. and Remedios, J. J.: Seasonality of Peroxyacetyl nitrate (PAN) in the upper troposphere and lower stratosphere using the MIPAS-E instrument, Atmos. Chem. Phys., 10, 6117-6128, https://doi.org/10.5194/acp-10-6117-2010, 2010.

Myhre, G., Shindell, D., Bréon, F.-M., Collins, W., Fuglestvedt, J., Huang, J., Koch, D., Lamarque, J.-F., Lee, D., Mendoza, B., Nakajima, T., Robock, A., Stephens, G., Takemura, T., and Zhang, H.: Anthropogenic and Natural Radiative Forcing, in: Climate Change 2013: The Physical Science Basis. Contribution of Working Group I to the Fifth Assessment Report of the Intergovernmental Panel on Climate Change, edited by: Stocker, T. F., Qin, D., Plattner, G.-K., Tignor, M., Allen, S. K., Boschung, J., Nauels, A., Xia, Y., Bex, V., and Midgley, P. M., Cambridge University Press, Cambridge, United Kingdom and New York, NY, USA, 2013.

Ohara, T., Akimoto, H., Kurokawa, J., Horii, N., Yamaji, K., Yan, X., and Hayasaka, T.: An Asian emission inventory of anthropogenic emission sources for the period 1980-2020, Atmos. Chem. Phys., 7, 4419-4444, https://doi.org/10.5194/acp-7-44192007, 2007.

Pandey Deolal, S., Staehelin, J., Brunner, D., Cui, J., Steinbacher, M., Zellweger, C., Henne, S., and Vollmer, M. K.: Transport of PAN and NOy from different source regions to the Swiss high alpine site Jungfraujoch, Atmos. Envron., 64, 103-115, https://doi.org/10.1016/j.atmosenv.2012.08.021, 2013.

Park, M., Randel, W. J., Gettelman, A., Massie, S. T., and Jiang, J. H.: Transport above the Asian summer monsoon anticyclone inferred from Aura Microwave Limb Sounder tracers, J. Geophys. Res., 112, D16309, https://doi.org/10.1029/2006jd008294, 2007.

Park, M., Randel, W. J., Emmons, L. K., Bernath, P. F., Walker, K. A., and Boone, C. D.: Chemical isolation in the Asian monsoon anticyclone observed in Atmospheric Chemistry Experiment (ACE-FTS) data, Atmos. Chem. Phys., 8, 757-764, https://doi.org/10.5194/acp-8-757-2008, 2008.
Park, M., Randel, W. J., Emmons, L. K., and Livesey, N. J.: Transport pathways of carbon monoxide in the Asian summer monsoon diagnosed from Model of Ozone and Related Tracers (MOZART), J. Geophys. Res., 114, D08303-D08313, https://doi.org/10.1029/2008jd010621, 2009.

Pope, R. J., Richards, N. A. D., Chipperfield, M. P., Moore, D. P., Monks, S. A., Arnold, S. R., Glatthor, N., Kiefer, M., Breider, T. J., Harrison, J. J., Remedios, J. J., Warneke, C., Roberts, J. M., Diskin, G. S., Huey, L. G., Wisthaler, A., Apel, E. C., Bernath, P. F., and Feng, W.: Intercomparison and evaluation of satellite peroxyacetyl nitrate observations in the upper tropospherelower stratosphere, Atmos. Chem. Phys., 16, 13541-13559, https://doi.org/10.5194/acp-16-13541-2016, 2016.

Qu, B., Ming, J., Kang, S.-C., Zhang, G.-S., Li, Y.-W., Li, C.-D., Zhao, S.-Y., Ji, Z.-M., and Cao, J.-J.: The decreasing albedo of the Zhadang glacier on western Nyainqentanglha and the role of light-absorbing impurities, Atmos. Chem. Phys., 14, 1111711128, https://doi.org/10.5194/acp-14-11117-2014, 2014.

Ramanathan, V., Ramana, M. V., Roberts, G., Kim, D., Corrigan, C., Chung, C., and Winker, D.: Warming trends in Asia amplified by brown clouds solar absorption, Nature, 448, 575-578, 2007.

Ran, L., Lin, W. L., Deji, Y. Z., La, B., Tsering, P. M., Xu, X. B., and Wang, W.: Surface gas pollutants in Lhasa, a highland city of Tibet - current levels and pollution implications, Atmos. Chem. Phys., 14, 10721-10730, https://doi.org/10.5194/acp-14-107212014, 2014.

Randel, W. J., Park, M., Emmons, L., Kinnison, D., Bernath, P., Walker, K. A., Boone, C., and Pumphrey, H.: Asian Monsoon Transport of Pollution to the Stratosphere, Science, 328, 611613, https://doi.org/10.1126/science.1182274, 2010.

Remedios, J. J., Allen, G., Waterfall, A. M., Oelhaf, H., Kleinert, A., and Moore, D. P.: Detection of organic compound signatures in infra-red, limb emission spectra observed by the MIPASB2 balloon instrument, Atmos. Chem. Phys., 7, 1599-1613, https://doi.org/10.5194/acp-7-1599-2007, 2007.

Roberts, J. M.: PAN and Related Compounds, in: Volatile Organic Compounds in the Atmosphere, edited by: Koppmann, R., Blackwell Publishing, Oxford, UK, 2007.

Roiger, A., Aufmhoff, H., Stock, P., Arnold, F., and Schlager, H.: An aircraft-borne chemical ionization - ion trap mass spectrometer (CI-ITMS) for fast PAN and PPN measurements, Atmos. Meas. Tech., 4, 173-188, https://doi.org/10.5194/amt-4173-2011, 2011.

Russo, R. S., Talbot, R. W., Dibb, J. E., Scheuer, E., Seid, G., Jordan, C. E., Fuelberg, H. E., Sachse, G. W., Avery, M. A., Vay, S. A., Blake, D. R., Blake, N. J., Atlas, E., Fried, A., Sandholm, S. T., Tan, D., Singh, H. B., Snow, J., and Heikes, B. G.: Chemical composition of Asian continental outflow over the western Pacific: Results from Transport and Chemical Evolution over the Pacific (TRACE-P), J. Geophys. Res., 108, 8804, https://doi.org/10.1029/2002jd003184, 2003.

Shen, R.-Q., Ding, X., He, Q.-F., Cong, Z.-Y., Yu, Q.-Q., and Wang, X.-M.: Seasonal variation of secondary organic aerosol tracers in Central Tibetan Plateau, Atmos. Chem. Phys., 15, 8781-8793, https://doi.org/10.5194/acp-15-8781-2015, 2015.

Singh, H. B.: Reactive nitrogen in the troposphere, Environ. Sci. Technol., 21, 320-327, 1987.

Singh, H. B., Salas, L., Herlth, D., Kolyer, R., Czech, E., Avery, M., Crawford, J. H., Pierce, R. B., Sachse, G. W., Blake, D. 
R., Cohen, R. C., Bertram, T. H., Perring, A., Wooldridge, P. J., Dibb, J., Huey, G., Hudman, R. C., Turquety, S., Emmons, L. K., Flocke, F., Tang, Y., Carmichael, G. R., and Horowitz, L. W.: Reactive nitrogen distribution and partitioning in the North American troposphere and lowermost stratosphere, J. Geophys. Res., 112, D12S04, https://doi.org/10.1029/2006JD007664, 2007.

Stull, R. B.: An Introduction to Boundary Layer Meteorology, Kluwer Academic, Dordrecht, The Netherlands, 1988.

Sudo, K., Takahashi, M., and Akimoto, H.: CHASER: A global chemical model of the troposphere 2. Model results and evaluation, J. Geophys. Res, 107, 4586, https://doi.org/10.1029/2001jd001114, 2002.

Talbot, R. W., Dibb, J. E., Scheuer, E. M., Kondo, Y., Koike, M., Singh, H. B., Salas, L. B., Fukui, Y., Ballenthin, J. O., Meads, R. F., Miller, T. M., Hunton, D. E., Viggiano, A. A., Blake, D. R., Blake, N. J., Atlas, E., Flocke, F., Jacob, D. J., and Jaegle, L.: Reactive nitrogen budget during the NASA SONEX Mission, Geophys. Res. Lett., 26, 3057-3060, https://doi.org/10.1029/1999GL900589, 1999.

Talukdar, R. K., Burkholder, J. B., Schmoltner, A.-M., Roberts, J. M., Wilson, R. R., and Ravishankara, A. R.: Investigation of the loss processes for peroxyacetyl nitrate in the atmosphere: UV photolysis and reaction with OH, J. Geophys. Res., 100, 1416314173, https://doi.org/10.1029/95JD00545, 1995.

Tereszchuk, K. A., Moore, D. P., Harrison, J. J., Boone, C. D., Park, M., Remedios, J. J., Randel, W. J., and Bernath, P. F.: Observations of peroxyacetyl nitrate (PAN) in the upper troposphere by the Atmospheric Chemistry Experiment-Fourier Transform Spectrometer (ACE-FTS), Atmos. Chem. Phys., 13, 5601-5613, https://doi.org/10.5194/acp-13-5601-2013, 2013.

Thakur, A. N., Singh, H. B., Mariani, P., Chen, Y., Wang, Y., Jacob, D.J., Brasseur, G., Müller, J. F., and Lawrence, M.: Distribution of reactive nitrogen species in the remote free troposphere: data and model comparisons, Atmos. Environ., 33, 1403-1422, https://doi.org/10.1016/s1352-2310(98)00281-7, 1999.

Tian, W., Chipperfield, M., and Huang, Q.: Effects of the Tibetan Plateau on total column ozone distribution, Tellus B, 60, 622635, 10.1111/j.1600-0889.2008.00338.x, 2008.

Ungermann, J., Ern, M., Kaufmann, M., Müller, R., Spang, R., Ploeger, F., Vogel, B., and Riese, M.: Observations of PAN and its confinement in the Asian summer monsoon anticyclone in high spatial resolution, Atmos. Chem. Phys., 16, 8389-8403, https://doi.org/10.5194/acp-16-8389-2016, 2016.

Volz-Thomas, A., Xueref, I., and Schmitt, R.: An automatic gas chromatograph and calibration system for ambient measureme, Environ. Sci. Pollut. R., 9, 72-76, 2002.

von Kuhlmann, R., Lawrence, M. G., Crutzen, P. J., and Rasch, P. J.: A model for studies of tropospheric ozone and nonmethane hydrocarbons: Model evaluation of ozone-related species, J. Geophys. Res., 108, 4729, https://doi.org/10.1029/2002jd003348, 2003.

Wang, M., Xu, B., Cao, J., Tie, X., Wang, H., Zhang, R., Qian, Y., Rasch, P. J., Zhao, S., Wu, G., Zhao, H., Joswiak, D. R., Li, J., and Xie, Y.: Carbonaceous aerosols recorded in a southeastern Tibetan glacier: analysis of temporal variations and model estimates of sources and radiative forcing, Atmos. Chem. Phys., 15, 1191-1204, https://doi.org/10.5194/acp-15-1191-2015, 2015.

Wang, T., Wong, H. L. A., Tang, J., Ding, A., Wu, W. S., and Zhang, $\mathrm{X}$. C.: On the origin of surface ozone and reactive nitrogen ob- served at a remote mountain site in the northeastern QinghaiTibetan Plateau, western China, J. Geophys. Res., 111, D08303, https://doi.org/10.1029/2005JD006527, 2006.

Wang, Q. Y., Gao, R. S., Cao, J. J., Schwarz, J. P., Fahey, D. W., Shen, Z. X., Hu, T. F., Wang, P., Xu, X. B., and Huang, R. J.: Observations of high level of ozone at Qinghai Lake basin in the northeastern Qinghai-Tibetan Plateau, western China, J. Atmos. Chem., 72, 19-26, 2015.

Wiegele, A., Glatthor, N., Höpfner, M., Grabowski, U., Kellmann, S., Linden, A., Stiller, G., and von Clarmann, T.: Global distributions of $\mathrm{C}_{2} \mathrm{H}_{6}, \mathrm{C}_{2} \mathrm{H}_{2}, \mathrm{HCN}$, and PAN retrieved from MIPAS reduced spectral resolution measurements, Atmos. Meas. Tech., 5, 723-734, https://doi.org/10.5194/amt-5-723-2012, 2012.

Worden, J., Jones, D. B. A., Liu, J., Parrington, M., Bowman, K., Stajner, I., Beer, R., Jiang, J., Thouret, V., Kulawik, S., Li, J.-L. F., Verma, S., and Worden, H.: Observed vertical distribution of tropospheric ozone during the Asian summertime monsoon, J. Geophys. Res., 114, D13304-D13320, https://doi.org/10.1029/2008jd010560, 2009.

Xiong, X., Houweling, S., Wei, J., Maddy, E., Sun, F., and Barnet, C.: Methane plume over south Asia during the monsoon season: satellite observation and model simulation, Atmos. Chem. Phys., 9, 783-794, https://doi.org/10.5194/acp-9-783-2009, 2009.

Xu, W., Lin, W., Xu, X., Tang, J., Huang, J., Wu, H., and Zhang, $\mathrm{X}$.: Long-term trends of surface ozone and its influencing factors at the Mt Waliguan GAW station, China - Part 1: Overall trends and characteristics, Atmos. Chem. Phys., 16, 6191-6205, https://doi.org/10.5194/acp-16-6191-2016, 2016.

Xu, W., Xu, X., Lin, M., Lin, W., Tarasick, D., Tang, J., Ma, J., and Zheng, X.: Long-term trends of surface ozone and its influencing factors at the Mt Waliguan GAW station, China - Part 2: The roles of anthropogenic emissions and climate variability, Atmos. Chem. Phys., 18, 773-798, https://doi.org/10.5194/acp-18-7732018, 2018.

Xue, L. K., Wang, T., Zhang, J. M., Zhang, X. C., Deliger, Poon, C. N., Ding, A. J., Zhou, X. H., Wu, W. S., Tang, J., Zhang, Q. Z., and Wang, W. X.: Source of surface ozone and reactive nitrogen speciation at Mount Waliguan in western China: New insights from the 2006 summer study, J. Geophys. Res., 116, F07306, https://doi.org/10.1029/2010jd014735, 2011.

Yeh, T.-C., Lo, S.-W., and Chu, P.-C.: The wind structure and heat balance in the lower troposphere over Tibetan Plateau and its surroundings, Acta Meteor. Sinica, 28, 108-121, 1957 (in Chinese).

Yin, X., Kang, S., de Foy, B., Cong, Z., Luo, J., Zhang, L., Ma, Y., Zhang, G., Rupakheti, D., and Zhang, Q.: Surface ozone at Nam Co in the inland Tibetan Plateau: variation, synthesis comparison and regional representativeness, Atmos. Chem. Phys., 17, 11293-11311, https://doi.org/10.5194/acp-17-112932017, 2017.

Zanis, P., Ganser, A., Zellweger, C., Henne, S., Steinbacher, M., and Staehelin, J.: Seasonal variability of measured ozone production efficiencies in the lower free troposphere of Central Europe, Atmos. Chem. Phys., 7, 223-236, https://doi.org/10.5194/acp-7223-2007, 2007.

Zellweger, C., Ammann, M., Buchmann, B., Hofer, P., Lugauer, M., Rüttimann, R., Streit, N., Weingartner, E., and Baltensperger, U.: Summertime $\mathrm{NO}_{y}$ Speciation at the Jungfraujoch, $3580 \mathrm{~m}$ asl, Switzerland, J. Geophys. Res., 105, 6655-6667, 2000. 
Zellweger, C., Klausen, J., Buchmann, B., and Scheel, H.-E.: System and Performance Audit of Surface Ozone, Carbon Monoxide, Methane and Nitrous Oxide at the GAW Global Station Mt. Waliguan and the Chinese Academy of Meteorological Sciences (CAMS) China, June 2009, WCC-Empa Report 09/2Rep., 61 pp., Empa, Dübendorf, Switzerland, available at: https://www.wmo.int/pages/prog/arep/gaw/documents/ WLG_2009.pdf (last access: 15 January 2018), 2009.

Zhang, H., Xu, X., Lin, W., and Wang, Y.: Wintertime peroxyacetyl nitrate (PAN) in the megacity Beijing: Role of photochemical and meteorological processes, J. Environ. Sci., 26, 83-96, https://doi.org/10.1016/S1001-0742(13)60384-8, 2014

Zhang, J. M., Wang, T., Ding, A. J., Zhou, X. H., Xue, L. K., Poon, C. N., Wu, W. S., Gao, J., Zuo, H. C., Chen, J. M., Zhang, X. C., and Fan, S. J.: Continuous measurement of peroxyacetyl nitrate (PAN) in suburban and remote areas of western China, Atmos. Environ., 43, 228-237, 2009.

Zhang, L., Jacob, D. J., Boersma, K. F., Jaffe, D. A., Olson, J. R., Bowman, K. W., Worden, J. R., Thompson, A. M., Avery, M. A., Cohen, R. C., Dibb, J. E., Flock, F. M., Fuelberg, H. E., Huey, L. G., McMillan, W. W., Singh, H. B., and Weinheimer, A. J.: Transpacific transport of ozone pollution and the effect of recent Asian emission increases on air quality in North America: an integrated analysis using satellite, aircraft, ozonesonde, and surface observations, Atmos. Chem. Phys., 8, 6117-6136, https://doi.org/10.5194/acp-8-6117-2008, 2008.

Zhang, Q., Streets, D. G., Carmichael, G. R., He, K. B., Huo, H., Kannari, A., Klimont, Z., Park, I. S., Reddy, S., Fu, J. S., Chen, D., Duan, L., Lei, Y., Wang, L. T., and Yao, Z. L.: Asian emissions in 2006 for the NASA INTEX-B mission, Atmos. Chem. Phys., 9, 5131-5153, https://doi.org/10.5194/acp-9-5131-2009, 2009.
Zhang, Q., Kang, S., and Zhang, G.: Changes of snow line altitude for glaciers on western Nyainqentanglha range observed by remote sensing, Scientia Geographica Sinica, 36, 1937-1944, 2016.

Zhang, R., Wang, H., Qian, Y., Rasch, P. J., Easter, R. C., Ma, P.L., Singh, B., Huang, J., and Fu, Q.: Quantifying sources, transport, deposition, and radiative forcing of black carbon over the Himalayas and Tibetan Plateau, Atmos. Chem. Phys., 15, 62056223, https://doi.org/10.5194/acp-15-6205-2015, 2015.

Zhao, S., Ming, J., Sun, J., and Xiao, C.: Observation of carbonaceous aerosols during 2006-2009 in Nyainqêntanglha Mountains and the implications for glaciers, Environ. Sci. Pollut. Res., 20, 5827-5835, https://doi.org/10.1007/s11356-013-1548-6, 2013.

Zheng, X. D., Shen, C. D., Wan, G. J., Liu, K. X., Tang, J., and $\mathrm{Xu}, \mathrm{X}$. B.: ${ }^{10} \mathrm{Be} /{ }^{7} \mathrm{Be}$ implies the contribution of stratospheretroposphere transport to the winter-spring surface $\mathrm{O}_{3}$ variation observed on the Tibetan Plateau, Chinese Sci. Bull., 56, 84-88, 2011.

Zhou, X., Lou, C., Li, W. L., and Shi, J. E.: Ozone changes over China and low center over Tibetan Plateau, Chinese Sci. Bull., 40, 1396-1398, 1995.

Zhu, L., Fischer, E. V., Payne, V. H., Worden, J. R., and Jiang, Z.: TES observations of the interannual variability of PAN over Northern Eurasia and the relationship to springtime fires, Geophys. Res. Lett., 42, 7230-7237, https://doi.org/10.1002/2015GL065328, 2015.

Zhu, T., Lin, W. L., Song, Y., Cai, X. H., Zou, H., Kang, L., Zhou, L. B., and Akimoto, H.: Downward transport of ozonerich air near Mt. Everest, Geophys. Res. Lett., 33, L23809, https://doi.org/10.1029/2006GL027726, 2006. 